\title{
A Century of Nonprofit Studies: Scaling the Knowledge of the Field
}

\author{
Published in \\ Voluntas (2018) 29: 1139. https://doi.org/10.1007/s11266-018-00057-5
}

\author{
Ji Ma \\ Lyndon B. Johnson School of Public Affairs, RGK Center for Philanthropy and Community Service \\ University of Texas at Austin \\ Sara Konrath \\ Lilly Family School of Philanthropy \\ Indiana University - Purdue University Indianapolis
}

Correspondence:

Ji Ma

maji@austin.utexas.edu

LBJ School of Public Affairs

2315 Red River Street

Austin, Texas 78712

USA

Email Addresses: Ji Ma, maji@austin.utexas.edu; Sara Konrath, skonrath@iupui.edu.

Compliance with Ethical Standards:

Funding: This work was supported in part by the John Templeton Foundation (\#47993 and \#57942 to S.K.) and the National Institutes of Health [1R21-HD073549-01A1 (NICHD) and 1R01-CA-180015 (NCI) to S.K.].

Conflict of Interest: The authors declare that they have no conflict of interest.

Acknowledgment: We thank Dr. Zhaonan Zhu and Sasha Zarins for their assistance with data preprocessing; Dr. Chao Guo, Dr. Diarmuid McDonnell, Dr. Femida Handy, Dr. Jeffrey Brudney, Dr. Richard Steinberg, Dr. Susan Phillips, Xunyu Xiang, and Dr. Zheng Yang for their comments and suggestions; Dr. Simon DeDeo for providing computing resources. Willow the cat also deserves special acknowledgement for her patient lap sleeping while writing this manuscript (with S.K.). Earlier versions of this paper were presented at the Association of SPEA Ph.D. Students Annual Conference 2015; Annual Conference of the Association for Research on Nonprofit Organizations and Voluntary Action 2015 and 2017. We thank the meeting participants for their comments during presentations. We also thank the anonymous reviewers for their constructive suggestions. 


\section{A Century of Nonprofit Studies: Scaling the Knowledge of the Field}

ABSTRACT .




\begin{abstract}
This empirical study examines knowledge production between 1925 and 2015 in nonprofit and philanthropic studies from quantitative and thematic perspectives. Quantitative results suggest that scholars in this field have been actively generating a considerable amount of literature and a solid intellectual base for developing this field towards a new discipline. Thematic analyses suggest that knowledge production in this field is also growing in cohesion - several main themes have been formed and actively advanced since the 1980s, and the study of volunteering can be identified as a unique core theme of this field. The lack of geographic and cultural diversity is a critical challenge for advancing nonprofit studies. New paradigms are needed for developing this research field and mitigating the tension between academia and practice. Methodological and pedagogical implications, limitations, and future studies are discussed.
\end{abstract}

Keywords: nonprofit and philanthropic studies; network analysis; knowledge production; paradigm shift; science mapping 


\section{INTRODUCTION}

Although the existence of voluntary and philanthropic organizations can date back to as early as the seventeenth century, the study of nonprofit organizations and philanthropy only begins in the 1890s (Hall 1999, 522), and the "inventing of the nonprofit sector” is only an recent endeavor from the mid-1970s (Hall 2006, 54). The foundamental theories of nonprofit organizations and philanthropy were produced by scholars from various mainstream disciplines, for example, history, sociology, and economics (Hall 1999, 523). Although the Filer Commission brought leading scholars together and construed nonprofit organizations as part a coherent and necessary sector of society (Hall 2006, 54-55), scholars were still skeptical about the academic identity and future development of this field. The scholarship on nonprofit studies was produced by researchers from other mainstream disciplines, and it was hard to attract first-rate scholars and graduate students into this field (Katz 1999, 78). As an emerging interdisciplinary research field, nonprofit and philanthropic studies requires a large developing body of theoretical and empirical knowledge to support its development, therefore emphasizing the importance of knowledge production in this research field.

This study examines "knowledge production" from two perspectives: the quantity of scholarly activities and the cohesion of scholarship. The former includes, for example, the number of journal articles published, the number of authors and institutions working in this research field, and the productivity of researchers. The latter examines whether the literature has formed several inter-connected research themes that can distinguish this research field - a prerequisite for forming its disciplinary identity. Few scholars approached this research topic from either the former or latter perspective (Brass, 
Longhofer, Robinson, \& Schnable, 2018; Brudney \& Durden, 1993; Bushouse \& Sowa, 2012; Jackson, Guerrero, \& Appe, 2014; Shier \& Handy, 2014). But there needs to be a more comprehensive analysis regarding the dataset and methodology.

As a study of knowledge production, this paper contributes from various theoretical and practical perspectives. Theoretically, understanding the main research topics and trends can serve as an "academic compass" for scholars and is useful for setting up research agendas, especially for emerging scholars. Less developed topics and theories could be advanced if scholars were aware of the gaps. It is also helpful for mitigating the discrepancies between theory and practice (Bushouse \& Sowa, 2012, p. 499). In terms of educational significance, studies of knowledge production can provide students with "a map of knowledge," helping them to better understand and navigate this field. This study is also useful for instructors in developing syllabi that cover the main topics in the field. Moreover, studies of knowledge production can provide more evidence for advancing this research area toward a more established discipline, allowing for broader representation of nonprofit and philanthropic studies departments or schools in universities.

Figure 1 illustrates the structure of this paper. The method section introduces datasets, data preprocessing procedures, and methods of analysis. The result section presents findings in two subsections. By using an innovative and large dataset recording the scholarship published in 19 journals between 1925 and 2015 worldwide, the first subsection describes the general trends of development of this research field in the last century, mainly supporting the quantitative aspect of knowledge production. The second subsection is a detailed thematic analysis of the literature published between 1986 and 
2015, mainly supporting the knowledge cohesion. Combing the two subsections, this paper provides empirical evidence for the institutionalization of this research field. We finally review the results and present some concluding remarks.

\section{METHOD}

This study is an empirical research project which uses network analysis and science mapping to model the scholarship produced in the field of nonprofit and philanthropic studies. These research methods are very helpful for understanding the evolution and structure of a research field (Adams, Lind Infeld, Wikrent, \& Bintou Cisse, 2016; Hu, Khosa, \& Kapucu, 2015; Korff, Oberg, \& Powell, 2015). Network analysis is an innovative research method that has been receiving more academic attention; it underpins some basic concepts in science mapping. Rather than giving a comprehensive introduction to each method, we only introduce key concepts employed in this study. We recommend some reviews for a deeper understanding of these methods (Börner, Theriault, \& Boyack, 2015; Carrington \& Scott, 2011; Noyons, 2001).

\section{Key Concepts in Network Analysis}

A network is a graph consisting of nodes (or vertices) and edges (or ties). The nodes represent entities of analysis, and the edges indicate their relationships (e.g., friend, coworker, graduate from the same school, etc.). Network analysis can be applied to different fields and is very powerful to study at a specific level of analysis - the network level, and a specific type of data - the relational data (Carrington \& Scott, 2011). 
Network density. This network profile measures the connectedness among nodes in a network, that is, the actual edges in proportion to all possible edges (Hanneman \& Riddle, 2011). Nodes in a higher density network tend to connect with each other more often, and information can be diffused more quickly in such networks.

Attachment probability. This node profile measures the node's ability to accrue new edges in an evolving network. Given a graph in state $t$, the node $i$ has $d$ edges; and in state $t+1, n$ new edges are attached to node $i$, and a total of $f$ new edges are added to the network in state $t+1$; therefore, the attachment probability of node $i$ in state $t$ is calculated as $\frac{n}{f}$ (Peirson, 2016). This metric can help us understand how network and nodes of interest evolve over time.

\section{Key Concepts in Science Mapping}

Science mapping explains "how disciplines, fields, specialties, and individual papers or authors are related to one another” (Small, 1999, p. 799). Numerous terms are used interchangeably by scholars to describe this method (e.g., Science of Science and Scientometrics). We use “science mapping” throughout.

Research front and intellectual base. The term research front was first introduced in 1965 to indicate a body of recently active scientific literature (Price, 1965, p. 512). The intellectual base was also suggested: some published articles are constantly cited and seem to be a part of an "eternal record of human knowledge” (Price, 1965, p. 515). Since then, the two concepts have been put forward by numerous scholars (e.g., Morris, Yen, Wu, \& Asnake, 2003; Persson, 1994). One of the most popular and recent definitions of research front is "emerging thematic trends and surges of new topics" (Chen, 2006, p. 
362), and intellectual base is defined as "citation trails of the research front in the literature" that can "change over time along with the movement of its research front" (Chen, 2006, p. 361).

Networks and science mapping. Research methods of science mapping usually include the analysis of co-author networks, co-citation networks, bibliographic coupling networks, and direct citation networks. In a co-author network, the nodes represent authors, and two nodes are connected if they have co-authored at least one paper. A cocitation network illustrates how previously published papers are cited by the academic community. Nodes in this network represent papers, and two papers are connected if they are both cited by a third paper. Co-citations suggest some thematic similarities between the two papers. A bibliographic coupling network measures how many references are shared by two articles. Nodes in this network represent papers, and two papers are connected if they cite the same references. In a direct citation network, nodes represent papers, and edges represent direct citations from one paper to another.

The selection of analytical methods depends on the analysis goals. For mapping current papers (i.e., the research front), researchers may use bibliographic coupling only. If the goal is to map classic papers from the current perspective (i.e., discovering the intellectual base), co-citation is more reliable and can discover the "core" of earlier literature in a particular academic specialty (Small, 1973, pp. 267-268, 1999, p. 802). Science mapping techniques and software packages are mainly built on these concepts and methods (Cobo, López-Herrera, Herrera-Viedma, \& Herrera, 2011).

\section{Datasets}


Dataset 1: Describing the overall trends, 1925-2015

When describing trends, the dataset should be as comprehensive as possible. We followed these steps to generate a collection of literature records from Scopus, the largest database of peer-reviewed publications that includes scientific journals, books, and conference proceedings (Elsevier 2017):

1. Identify a list of core journals in the field. Smith (2013) identified 61 core journals serving this field, defined by having "relevant terms like civil society, third sector, social economy, philanthropy, social movements, nonprofit organizations, participation, engagement, and so forth, in their titles or subtitles” (p. 654).

2. Retrieve all the papers published in the core journals that indexed by Scopus. The 61 core journals are meant to be comprehensive, but they deviate greatly on quality. For example, some of the journals have no International Standard Serial Number (ISSN), such as Giving - Thematic Issues in Philanthropy and Social Innovation and the Journal of China Philanthropy Studies. Some of the journals publish irregularly, for example, the 3Cmedia: Journal of Community, Citizen's and Third Sector Media has no publication between 2013-2015. This step narrowed down the number of journals to 19 .

3. We only included: articles, articles in press, conference papers, reviews, and short surveys. Editorials, book reviews, and erratum were excluded.

The three steps generated a collection of 12,016 bibliographic records from 19 journals published between 1925-2015 (both ends included) worldwide. Each bibliographic record consists of various data fields including the title of the citing article, 
author's name, publication year, publication title, and the article's cited references (these terms will be used throughout this paper to ensure consistency). The cited references have 311,212 entries including journal articles, books, dissertations, and technical reports, etc.

Dataset 1 is possibly the most comprehensive one of its kind to date. First, unlike studies that only use articles published in a specific journal, this dataset consists of all important journals identified by scholars. Second, although we excluded some journals, this was necessary to ensure the quality of data. Third, literature published elsewhere and in other forms (e.g., books or book chapters) is also included because the 311,212 cited references include publications other than journal articles (e.g., books, dissertations, and technical reports), thus expanding our analysis to various types of references.

Dataset 2: Deeper thematic analysis, 1986-2015

For thematic analysis, the dataset must include the "core" scholarly works of nonprofit and philanthropic studies. It is important to use journals dedicatedly serving this field as our data source; otherwise, the uniqueness and identity of this area can be diluted by other disciplines. A general consensus is that Nonprofit Management and Leadership (NML), Nonprofit and Voluntary Sector Quarterly (NVSQ), and Voluntas are the only three journals indexed by the Social Science Citation Index (SSCI) and exclusively serving this field (Bernick \& Krueger, 2010; Brudney \& Herman, 2004). We therefore use literature published in these three journals between 1986-2015 as the dataset for a deeper thematic analysis.

We followed similar steps as aforementioned to generate Dataset 2 from Scopus and Web of Science. Records from Scopus were converted into the Web of Science 
standard format because the two databases were in different formats. There was a loss while converting, and the converting rate of this study (89\%) is good for analysis because: 1) it is close to the "very decent successful rate," which is 95\% (Chen, 2014, p. $66), 2$ ) the records not converted tended to be references that were less cited.

Similar to Dataset 1, each bibliographic record of Dataset 2 consists of various data fields including the title of citing article, author's name, publication year, publication name, and the article's cited references. The cited references also include various types of academic publications or technical reports.

Overall, Dataset 2 consists of 2,848 bibliographical records spanning from 1986 to 2015 , and 51,945 cited references in various types. See Table 1 for dataset composition.

[Table 1 about here]

Because of the limitation of databases, the records from 1989 are missing, and the $N M L$ 's data is incomplete. For the missing records of 1989, we expect there should be minor influences on our analysis because we are mainly using co-citation analysis - the literature published in 1989 may be cited by the papers published later and therefore may be included in the analysis. The incompleteness of the NML's data may undermine the clustering analysis - some of the topics that are practice-oriented may be less represented.

\section{Data preprocessing for thematic analysis}

Data retrieved from bibliographic databases contain errors and require preprocessing. Three aspects need attention: duplicate records, time slicing, and data reduction (Cobo, López-Herrera, Herrera-Viedma, \& Herrera, 2011, pp. 1384-1385). 
Because of page limits, detailed methodology of data preprocessing is posted online (http://bit.ly/30npo).

Duplicate records. Duplicate records are common errors in raw data when the same cited reference may be recorded differently. For example, the same article may be cited as “ABZUG R, 1996, NONPROFIT MANAGEMENT, V7, P101” and “ABZUG R, 1996, NONPROFIT MANAGEMENT AND LEADERSHIP, V7, P101-111.” In this situation, the two records will be erroneously treated as two different articles. Approximately 400 duplicate records were corrected (about 13\% of all cited references in the final co-citation network).

Time slicing. Time slicing divides the dataset into different sub-periods. It is necessary for longitudinal studies and useful for analyzing the evolution of a research field. A bibliographical network can be constructed for each period, and the networks are the "snapshots" of the periods for analysis. Scholars can trace the changes of these networks to understand the knowledge evolution.

Data reduction. Scholars typically use data reduction methods to focus on the most important data. This is necessary to discover patterns and save computational resources, especially in network analysis. For example, they may only include the most frequently cited articles or journals with high impact factors to keep their analysis focused on the most influential literature (Cobo et al., 2011, p. 1385).

\section{RESULTS}

\section{Describing the overall trends, 1925 - 2015}

Productivity of scholarly activities 
[Figure 2 about here]

Figure 2 illustrates the number of publications and core journals in this field from 1925-2015. Before 1972, the Annals of Public and Cooperative Economics was the only journal in this field and only produced about 30 papers per year on average. A series of events after 1972 facilitated the publications: 1) In 1972, the Journal of Voluntary Action Research (JVAR), the predecessor of NVSQ, became the second journal serving this field dedicatedly, and it was included in SSCI in 1997; 2) In 1973, the Commission on Private Philanthropy and Public Needs (i.e., the Filer Commission) was organized and had a critical role in inventing the concept “nonprofit sector” (Hall 2006, 54-55); 3) In 1990, another two important journals in this field came out, i.e., Voluntas and $N M L$, and the two journals became SSCI-indexed in 2011. In 2015, 628 papers were published by 19 key journals in this field.

[Figure 3 about here]

Figure 3 shows the distribution of institutions by time periods. We note several features of this figure: 1) Between 1925-1950, more than $40 \%$ of the articles' affiliations were in Switzerland (24.3\%) and Germany (21.5\%); 2) institutions from China showed up as early as those from the western countries, but disappeared completely between 1951-1975; 3) after the mid-1970s, institutions are distributed unevenly, and a majority of them (more than 30\% but less than 50\%) are from the United States. These findings may echo some historical and political facts, for example, the relocation of research base from Europe to the United States and "civil society" as a politically sensitive concept especially during the Cold War time.

[Figure 4 about here] 
Figure 4 shows the distribution of cited references by citation counts and time periods. A total of 311,212 references were cited between 1971-2016 in this field (no citation information was available in the database before 1971). Price (1965) estimated that only a small proportion of all the scientific literature is cited, and along with the increase of citation counts $(x)$, the percentage of papers that are cited for $x$ times will decrease to $x^{2.5}$ or $x^{3}$ (p.511). For example, the percentage of papers that are cited 5 times $(x=2)$ should be between $1.79 \%\left(5^{-2.5}\right)$ and $0.8 \%\left(5^{-3}\right)$. The citing behavior in this field headed towards the area between $x^{2.5}$ and $x^{3}$ (dashed lines), suggesting that references became neither over-cited nor less-cited compared to the overall scientific community - this is evidence of the maturity of the field of nonprofit and philanthropic studies.

[Table 2 about here]

A total of 10,135 authors from 3,506 institutions worldwide have contributed to this research field. Table 2 shows the top 20 institutions by the number of papers produced. Congruent with previous research, this field is dominated by US institutions (Shier and Handy 2014). For the top 20 institutions, each author contributed about 1.36 journal articles on average, which is much larger than the number in public administration (0.98; Ni, Sugimoto, and Robbin 2017, 4).

Periodization of the development of nonprofit and philanthropic studies

[Figure 5 about here]

Figure 5 puts together major trends in scholarly activities by year, including the number of journals, articles, institutions, countries, authors, and cited sources. By using 
Kuhn’s (1970) notions of "paradigm” and “normal science,” the development of nonprofit and philanthropic studies in the last century has gone through three stages:

1. Pre-paradigm period (1920s-1960s) features early interest in public economics, for example, the articles published in the Annals of Public and Cooperative Economics.

2. Paradigm-building period (1970s-1980s) emphasizes the fundamental theories of the nonprofit sector, for example, three-failure theories (Salamon, 1987a; Weisbrod, 1975, 1977).

3. Normal science period (1990s-2010s) features a steady growth of scholarly activities. The first wave of booming (1990s) may be driven primarily by the theoretical paradigms built in the prior period - allowing researchers to use existent theories and paradigms to accrue and extend current knowledge (Kuhn, 1970, p. 35). The second wave of booming (2000s-2010s) may be attributed to the dramatic increase of institutional representation in universities, for example, the development of graduate programs and the establishment of research centers (Mirabella, 2007; Mirabella \& Wish, 2001).

\section{Deeper Thematic Analysis 1986 - 2015}

Describing the overall trends

[Figure 6 about here]

The number of articles published in the three journals increased from less than 50 per year to nearly 200 per year, a 4-fold increase over the last 30 years (Figure 6). Two major efforts contribute to this achievement: the growth of journal volumes published 
each year and the inclusion in the Journal Citation Reports (JCR). Before 1990, only NVSQ/JVAR was consistently serving this field. Although NML and Voluntas were established in 1990, they only produced limited, sometimes even irregular numbers of issues per year (e.g., NML published 6 issues in 1996 and then 2 issues in 1997; Voluntas published 4 issues in 1994 and 3 issues in 1995). After 2000, all three journals published quarterly, and NVSQ started to publish bi-monthly from 2009 onward, followed by Voluntas from 2014 onward. Although NVSQ was included in JCR from 1997, NML and Voluntas were only indexed after 2011. The inclusion of these three journals in JCR is critical not only for these three journals but also for nonprofit studies because it allows a broader circulation of literature on nonprofits in the academic community, which can help to form a scholarly identity of nonprofit studies.

[Figure 7 about here]

Figure 7 illustrates the unbalanced distribution of papers by country. More than half $(60.7 \%)$ of the papers in this field were authored with affiliations in the United States, followed by Canada (5\%), UK (4\%), and the Netherlands (1.6\%). This is congruent with Shier and Handy's (2014, p. 820) finding using dissertations and theses.

[Figure 8 about here]

Figure 8 shows the number of nodes and network density for four main bibliographic networks by year: the co-author network, co-citation network, bibliographic coupling network, and direct citation network. In general, in terms of the number of nodes in networks (bar), the four subplots all show significant increases over time, suggesting that this research field is becoming active. Several highlights worth noticing: 
1) The co-author network in Figure 8 shows a steady increase in the number of scholars in the collaboration network, and the decreasing network density signifies that collaborations are becoming widespread.

2) The rapidly increasing number in the co-citation network, especially after 2010, indicates that more literature has been incorporated into the intellectual base.

3) Although the number of coupled papers has significantly increased, the density of bibliographic coupling networks kept steady. This suggests the formation of several research topics that consistently attracted scholars' interests over the three decades, supporting the knowledge cohesion of this research field.

In general, the quantity of scholarly activities (Figure 5) and bibliographical

networks (Figure 8) suggest that nonprofit and philanthropic studies is an active research field with cohesive knowledge production.

Major research topics in the field

[Figure 9 about here]

A co-citation network with 672 nodes (cited references) was constructed and divided into 28 clusters. Each cluster represents a research topic. Figure 9 shows all the clusters and their mean citation counts. The most cited clusters include: Cluster \#27, \#0, $\# 7$, \#5, \#11, \#9, \#10, \#22, and \#17. ${ }^{1}$ These clusters can be recognized as scholars' major research interests and further divided into five categories (Table 3) introduced by Shier and Handy (2014, p. 816).

\footnotetext{
${ }^{1}$ The cluster number is determined by computer program. In order consistently present the findings with raw data posted online (.tsv file, "Python ClusterID” column), we did not rename the cluster number. See detail methodology http://bit.ly/30npo .
} 
[Table 3 about here]

[Figure 10 about here]

The network visualization (Figure 10) and topology of the graph can help us understand the relationship between different topics. For example, Cluster \#9: Organizational accountability only connects with Cluster \#11: Organizational effectiveness, suggesting a close relationship between accountability and effectiveness. The connection between Cluster \#5: Origins of nonprofit sector and Cluster \#22: Economic analysis of nonprofit sector reveals the role of economic theories in explaining origins of the nonprofit sector. Cluster \#17: Contracting and resource management is widely connected with numerous other clusters, suggesting this topic is pertinent to various topics. Cluster \#27: Theories of volunteering is in the central position of the network, indicating its core role in nonprofit and philanthropic studies.

Due to page limits, only the largest three topics (based on the number of articles in each topic) are briefly reviewed in this subsection. Another two clusters with distinctive evolving patterns are discussed in the following subsection.

[Table 4 about here]

Cluster \#27: Theories of volunteering (Table 4). Volunteering involves activities in which "time is given freely to benefit another person, group, or cause" (Wilson, 2000, p. 215). Papers in this cluster mainly examine the preconditions, motivations, and consequences of volunteering. Wilson and Musick are the two scholars most cited in this cluster (Musick \& Wilson, 2008; Musick, Wilson, \& Bynum, 2000; Wilson, 2000; Wilson \& Musick, 1997, 1999). Wilson’s (2000) paper published in Annual Review of 
Sociology is the most cited paper ${ }^{2}$, which synthesizes theories about volunteering from various perspectives (e.g. motives, values, and beliefs, human capital, exchange theory, and social resources). He also suggests some promising directions for future research, for example, the contribution of volunteering to citizenship and the role of community organizations in developing "new ideas of democratic politics and citizenship” (Wilson, 2000, p. 234). These suggestions directly relate to the nature of nonprofit sector, for example, as potential “schools of citizenship” (Clemens, 2006, p. 207).

[Table 5 about here]

Cluster \#0: Social capital and civic engagement (Table 5). Social capital has been widely examined by scholars in various disciplines and is relevant to nonprofit and philanthropic studies in many ways. For example, nonprofits can create social capital among citizens, and social capital is a core concept in community development (Wolfgang, 2004). After the introduction of this term in contemporary social science (Coleman, 1988; Bourdieu, 1986), Putnam later defined social capital as connections between individuals, and linked this concept with civic engagement (Putnam, 1995, 2000; Putnam, Leonardi, \& Nanetti, 1993). Social capital has since then received a lot of attention from scholars of nonprofit and philanthropic studies. However, Schuller, Baron, and Field (2000, pp. 26-27) pointed out definitional and measurement issues of this term. Various definitions of "social capital" have been developed, but they are operationalized in very different ways. This lack of consistency raises the critique that social capital is a conceptual entity widely used by scholars to "explain everything.” The validity of data for analyzing social capital is also questionable, and a mixture of quantitative and

\footnotetext{
${ }^{2}$ Citation count represents the number of times that the paper is cited by all the other articles in Dataset 2 .
} 
qualitative methods may be more appropriate. Glaser’s (1967) book on grounded theory also holds a prominent position in this cluster, suggesting that this popular qualitative research method is employed by many scholars who study social capital.

\section{[Table 6 about here]}

Cluster \#7: Organizational theories and collaboration (Table 6). The top 3 most cited references in this cluster are classic articles (regarding citation counts) on new institutionalism (DiMaggio \& Powell, 1983; Meyer \& Rowan, 1977) and resource dependency theory (Pfeffer \& Salancik, 1978). These two theories developed by sociologists have had a significant impact on studying organizational behavior. Other references in this cluster are mainly about cross-sector collaboration (Austin, 2000; Eikenberry \& Kluver, 2004) and intra-sector collaboration (Guo \& Acar, 2005). This suggests that the two theories became popular in this field because of studying collaboration - a research theme started in the 1980s that is still on the rise (Gazley \& Guo, 2015, p. 2). Gazley and Guo (2015) have suggested that there is a scarcity of theoretical work on this topic: “the ‘Big Four’ of Resource Dependence, Network, Transaction and Institutional Theories dominate the nonprofit collaboration literature” and "other theories may be underutilized" (p. 24). Our finding suggests that the situation may be even worse: among the four theories, only two of them are widely used. As research interest in collaboration grows, scholars and course instructors should introduce diverse theories on this topic.

Evolution of research interests

[Figure 11 about here] 
Figure 11 shows the mean attachment probability (AP) value of each cluster over time (references are aggregated by clusters). This figure illustrates how major research topics evolve over time. Most of these topics emerged in the mid-1980s with AP values above zero, indicating these topics have been actively developed by scholars ever since the mid-1980s. Cluster \#5, \#9, and \#10 are three clusters with special patterns.

[Table 7 about here]

Cluster \#5: Origins of nonprofit sector (Table 7). This cluster has received consistent academic attention from the mid-1980s until the 2000s. The nonprofit sector did not get its independent identity as a field of inquiry until "market failure / government failure” theory was developed by Weisbrod $(1975,1977)$. This earliest dominant theory explaining why the nonprofit sector exists led scholars to focus on two primary activities that nonprofits undertake in relation to the state, that is, service provision and advocacy, and two principal roles of nonprofits in democracy, that is, developing civic engagement and building social capital within citizens (Salamon, 1987b, 1995). Numerous other theories have also been used by scholars such as supply-side theory, trust theories, welfare state theory, and interdependence theory (Salamon \& Anheier, 1998, p. 213). However, none of these theories alone is adequate for understanding why nonprofit sectors exist in different countries, suggesting a complex "social origins approach" in which the nonprofit sector arises from interactions between institutional, social, political, and economic relationships (DiMaggio \& Anheier, 1990; Salamon \& Anheier, 1998). After the 2000s, the average AP value of this cluster significantly decreased but was still above zero, suggesting less academic interest in this topic. Moreover, the variance of AP values also decreased, indicating that scholars tended to regularly cite some classic pieces 
on this topic. These results support some scholars' claim that theorizing the origins of nonprofit sector has come into a period of "theoretical innovations and refinements" along with "theoretical inertia” (Anheier \& Ben-Ner, 1997, pp. 94-95), and there needs to be a "paradigm shift" for understanding why the nonprofit sector exists (Corry, 2010; Wagner, 2012).

[Table 8 about here]

Cluster \#9: Nonprofit accountability (Table 8). This topic is relatively new and emerged in the late 1990s. Accountability refers to "the means by which individuals and organizations report to a recognized authority (or authorities) and are held responsible for their actions” (Edwards \& Hulme, 1996, p. 967). One of the major paradigm shifts happened after the early 2000s: rather than a binary, short-term, and rule-following relationship between nonprofits and their stakeholders (e.g., funders and clients), accountability is a dynamic process characterized by organizational learning and backand-forth interactions with various stakeholders (Benjamin, 2008; Ebrahim, 2005).

\section{Disciplinary identity of nonprofit and philanthropic studies}

As an emerging interdisciplinary field, nonprofit and philanthropic studies is built by “many hands” from established disciplines, for example, sociology, history, and political science (Hall, 1999). Scholars in this field have long been puzzled by what the “core” of nonprofit studies is.

We use betweenness centrality to operationalize this question because node with high betweenness centrality has a critical role in controlling information flow - a “structural hole” position for connecting different clusters (Burt, 1992). As Table 9 
shows, this field is built by "many hands" in sociology and political science indeed, because many of the top 10 studies are published in the two well-established disciplines. However, important literature on volunteering (i.e., \#4 and \#7) is published by the journal serving this field dedicatedly (i.e., NVSQ), and the scholarship produced in nonprofit studies has also influenced other disciplines (e.g., religious studies and sociology) according to the column "Journals Mostly Citing.” Therefore, the study of volunteering can be identified as one of the "unique cores" of nonprofit and philanthropic studies.

\section{CONCLUDING REMARKS}

Scholars have been questioning whether nonprofit and philanthropic studies is a "serious research area," and whether the knowledge production in this field can support its development towards a discipline (Hall, 1999; Katz, 1999). By examining knowledge production between 1925 and 2015 from quantitative and thematic perspectives, this study supports the institutionalization of this field with empirical results obtained through scientific research methods. The raw data of this study can also serve important educational purposes.

\section{Maturity of Nonprofit Studies: Active Research Field with a Solid Intellectual Base}

The quantitative analysis of scholarly activities between 1925 and 2015 suggests there were three periods of development in this field: pre-paradigm period (1920s1960s), featuring early interests in public economics; paradigm-building period (1970s1980s), emphasizing fundamental theories of the nonprofit sector; and normal science period (1990s-2010s) featuring a steady growth of scholarly activities. Throughout all 
these phases, nonprofit studies has engaged a large number of scholars and generated a considerable amount of literature. The intellectual base is growing regarding the number of references incorporated in the co-citation network, suggesting a solid backing for the maturity of nonprofit studies. The three core journals, NML, NVSQ, and Voluntas, have critical roles in attaining this outcome. Arguments have arisen about whether there should be more journals serving this field: proponents suggest that there will be more opportunities for publication and expanding this field, while opponents claim there will be more inappropriate competition. Our finding supports the first argument which is congruent with Brudney and Herman (2004, p. 300): the rapidly increasing number of publications has greatly advanced the intellectual base of this field.

The knowledge in this field is growing not only in quantity, but also in cohesion. The analysis of bibliographic coupling shows that the published papers consistently share some cited references in common, indicating the formation of several main themes in the knowledge base. The pattern of citation counts suggests that the research activities in this field are becoming stable. Further analysis of the co-citation network reveals nine major themes in this field. The top three themes are theories of volunteering, social capital and civic engagement, and organizational theories and collaboration.

The geographic analysis suggests a serious challenge: the problem of low geographic and cultural diversity. The vast majority of the literature is produced by socalled "Anglosphere” countries - a loose coalition of English-speaking nations that share a common language, heritage, and even the same theoretical paradigms (Salamon, 2012, pp. 367-368). Bennett (2007) suggests that the Anglosphere features a particularly robust and independent civil society, but also geopolitical challenges which are intensified by 
economic and cultural gaps between the Anglosphere and elsewhere. Of course, it is possible that papers produced in the United States are about China or Russia, but unless indigenous academic efforts are also incorporated, this field can hardly become a global academic endeavor, let alone contribute to a better understanding of "global civil society.” Even worse, nonprofit studies as an academic research field may be distorted by political concerns. For example, one of the state leaders in China has interpreted civil society as “trap” set by "Western countries” (Simon, 2013, p. xxx). Future academic and editorial activity must involve more scholars from underrepresented countries and diverse cultural and historical perspectives.

\section{Tension between Academia and Practice: Importance of New Paradigms}

Academic research and practice need to match their progress and build conversations. For example, practitioners have expressed that studies of governmentnonprofit relations (represented by Cluster \#5) and citizen participation (represented by Cluster \#0) were no longer needed in the early 1990s (Brudney \& Kluesner, 1992, p. 304). But as Figure 11 shows, the two topics still attracted lot of scholarly attention even a decade later. On the contrary, research of organizational accountability (Cluster \#9), which is more pertinent to practitioners, only received increasing scholarly popularity in the late 1990s.

Some scholars suggest that in order to mitigate the tension between academic research and practice, there needs to be more collaboration between scholars and practitioners. Theoretical studies may not have immediate applied implications for practitioners, but basic knowledge is essential for the development of nonprofit studies as 
a field of scholarly inquiry (Brudney \& Kluesner, 1992). Through appropriate translation, these theoretical studies may have a significant impact on practice. Therefore, one of the solutions for mitigating the tension is the "communication process between academics and practitioners and their ability to share and/or jointly produce knowledge” (Bushouse \& Sowa, 2012, p. 500).

This paper suggests another possible approach: the formation and transformation of new academic paradigms. Scholars' research agenda and academic priorities are more influenced by the "groundbreaking studies" - studies that can lead the creation of new paradigms. As Kuhn (1970, p. 35) describes, researchers tend to work on "puzzlesolving” using existing theories and paradigms to accrue and extend current knowledge, rather than produce major new theories. Most of the topics illustrated in Figure 11 are boosted by the "groundbreaking studies." For example, the peak of Cluster \#0: Social capital and civic engagement was boosted by Putnam and his colleagues' work (1995, 2000; 1993). Cluster \#7: Organizational theories and collaboration was boosted by the development of new institutionalism. Cluster \#9: Organizational accountability was advanced by the shift from a static view to an dynamic view - the organizational learning and interactions among stakeholders (Ebrahim, 2005; Edwards \& Hulme, 1996, p. 969). In order to attract more scholars working on a specific topic, a theoretical paradigm needs to be built in the first place.

\section{Pedagogical Implications}

Abundant educational resources, such as introductory textbooks, specified databases, and online indices of scholarship, are indispensable for developing an 
academic field because future scholars in this field are trained using these resources. But as an emerging research discipline, educational resources for nonprofit and philanthropic studies are scarce.

Thus, this study can also serve important pedagogical purposes. As Figure 10 shows, the network topology of knowledge is very helpful for developing a syllabus introducing basic theories on nonprofit studies. For example, Cluster \#27: Theories of volunteering can be the first module in a syllabus because it is central in the knowledge map. The Cluster \#5: Origins of nonprofit sector and Cluster \#22: Economic analysis of nonprofit sector should be aligned together because they are theoretically connected. The most cited references in each cluster are indispensable for students to understand the theme. More usage can be discovered from the raw dataset posted online (http://bit.ly/30npo).

\section{Limitation and Future Studies}

Two major concerns of this study are the representativeness and comprehensivenss of the dataset. As an interdisciplinary area, a substantial amount of literature on nonprofit and philanthropic studies comes from the humanities, typically published in book form (e.g., Bremner, 1988; Payton \& Moody, 2008). Therefore, this study may underestimate the activities and scope of nonprofit studies by only using journal articles as citing references even though the cited references include literature in various forms. Many articles may also be published in languages other than English. Future research should attempt to address this limitation by incorporating other types of publications in more languages. 
As the first empirical study in the series, this descriptive study focuses on the landscape of nonprofit and philanthropic studies. Future studies can extend our understanding of this interdisciplinary field by 1) examining the economic, political, and cultural drivers of knowledge production, and 2) understanding interdisciplinary interactions, for example, how public administration, business, and social work have informed and influenced by nonprofit and philanthropic studies. 
Figure 1. Workflow and paper structure.

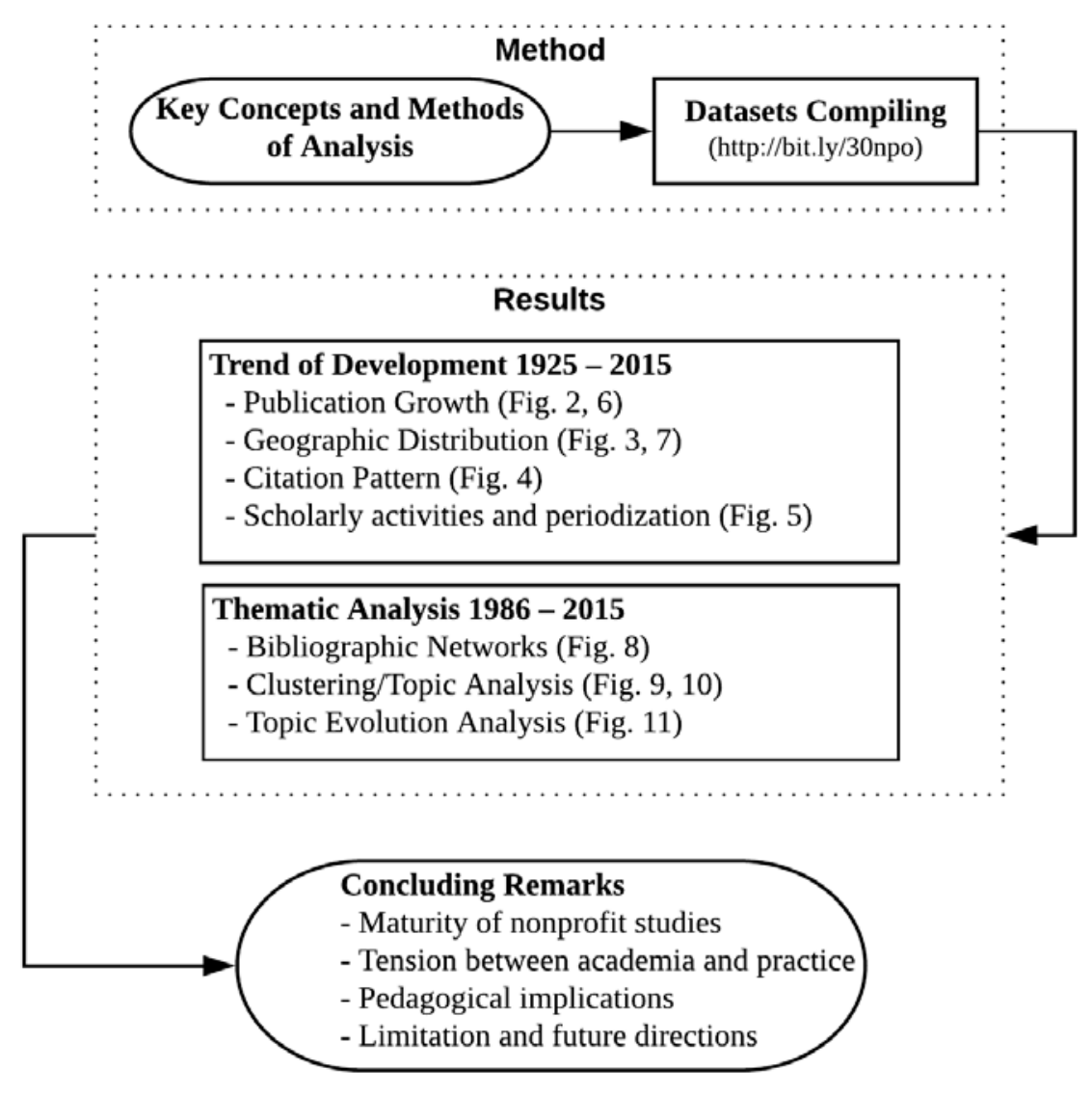


Figure 2. Number of journal articles and journals by year 1925-2015.

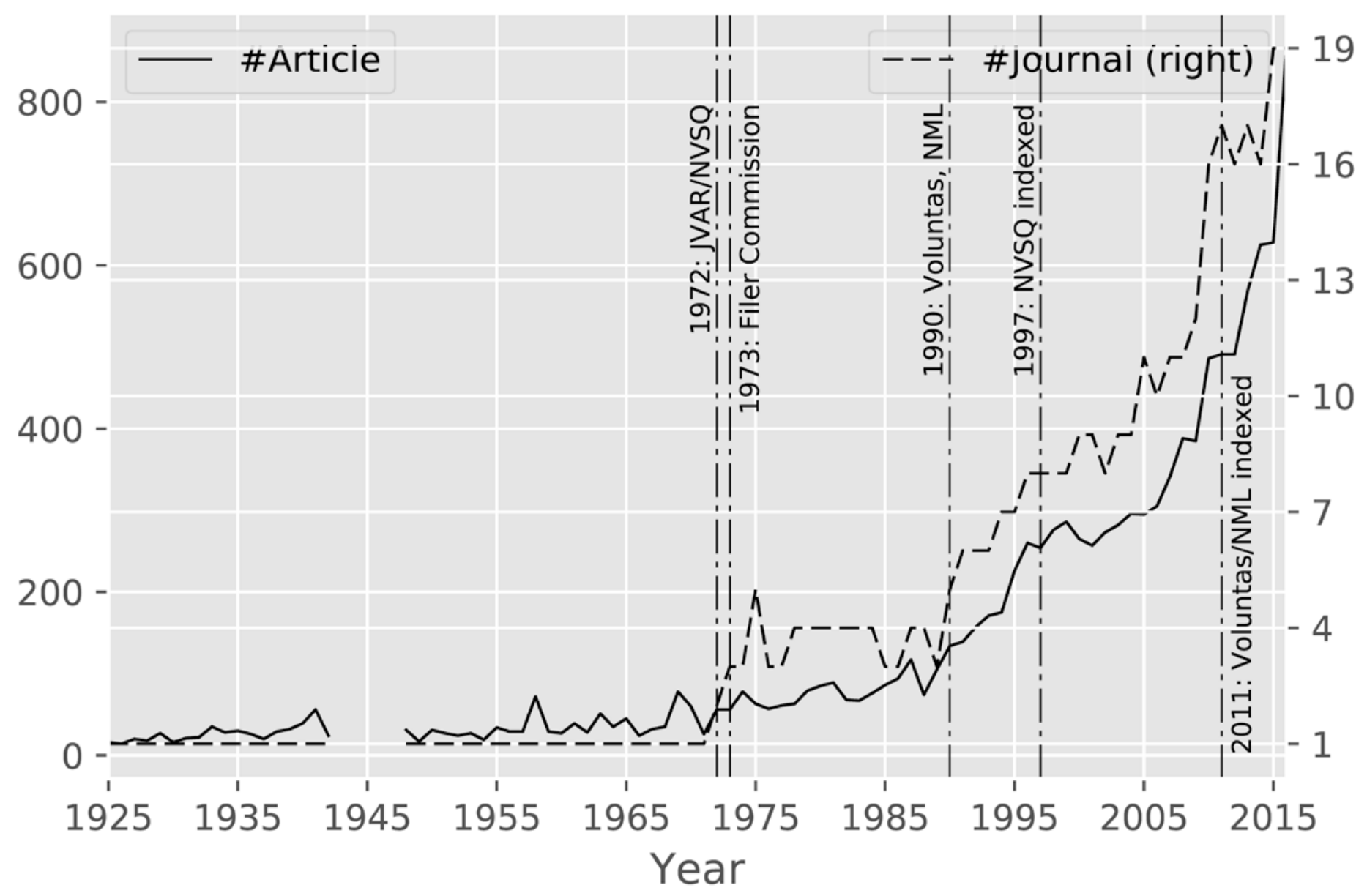


Figure 3. Distribution of institutions by country and time periods.

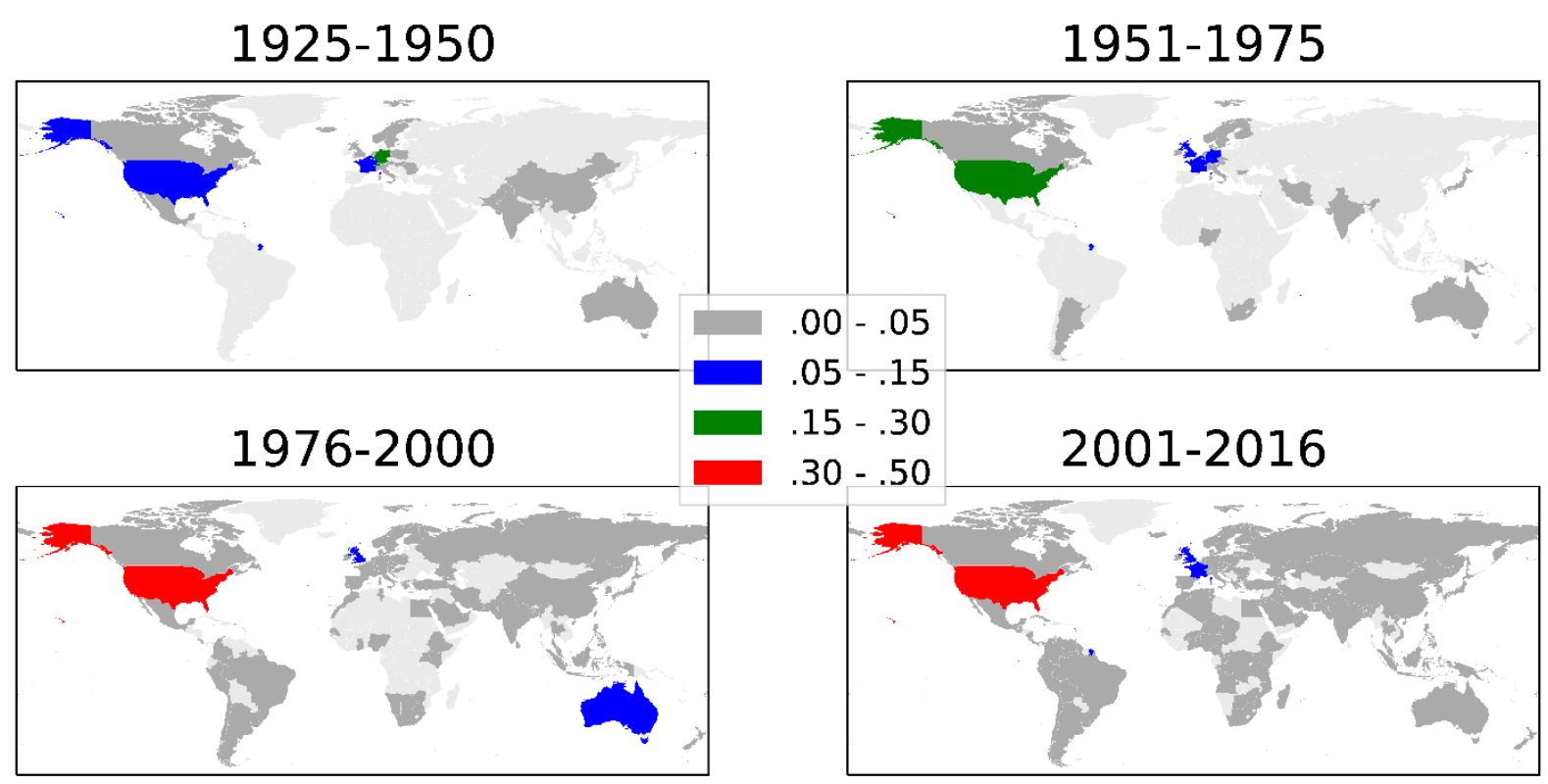

Note: Using ISO 3166 standard; the authors remain neutral regarding jurisdictional claims in maps. 
Figure 4. Distribution of cited references.

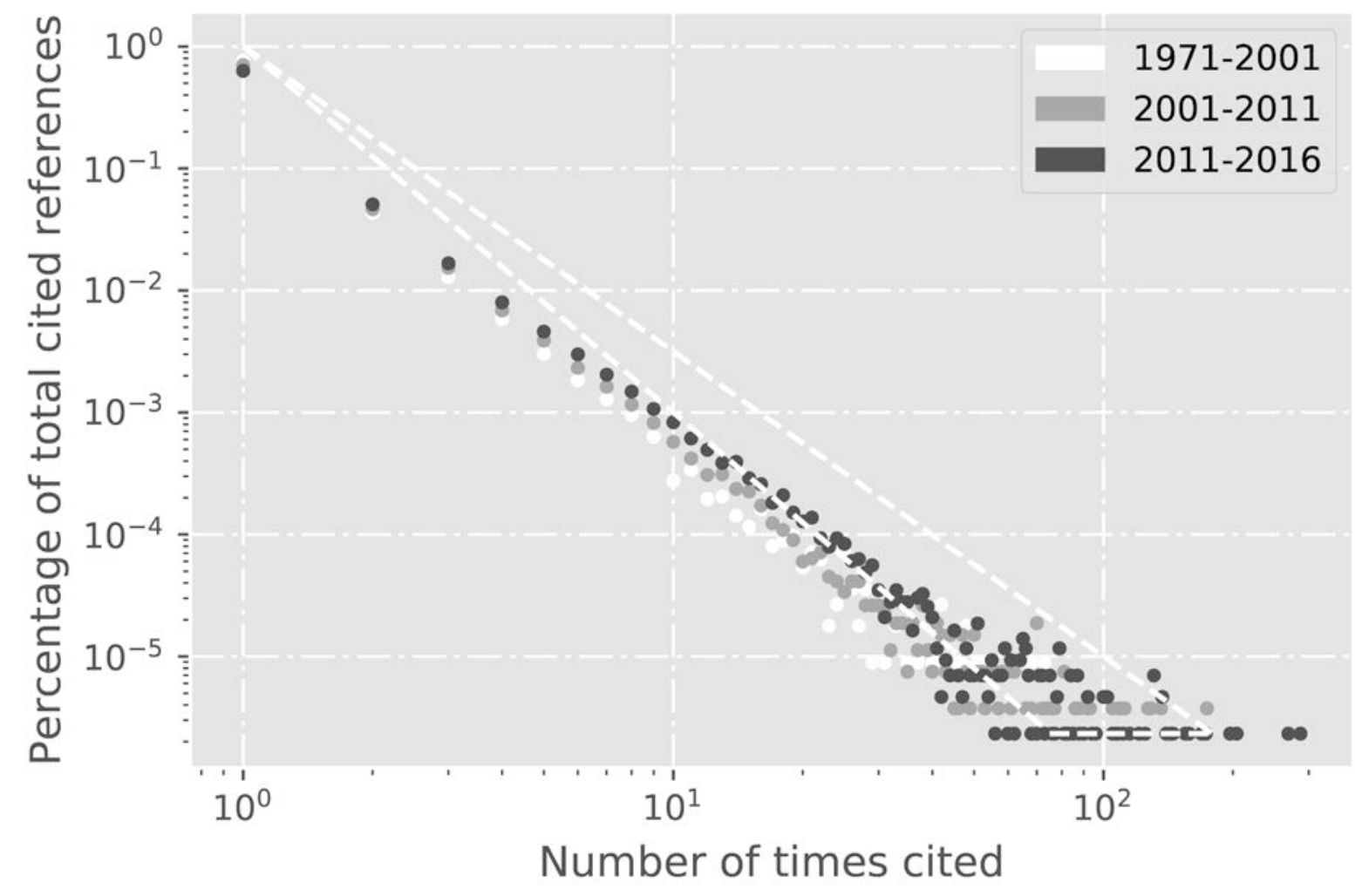


Figure 5. Major trends of scholarly activities and periodization in nonprofit and philanthropic studies 1925-2015.

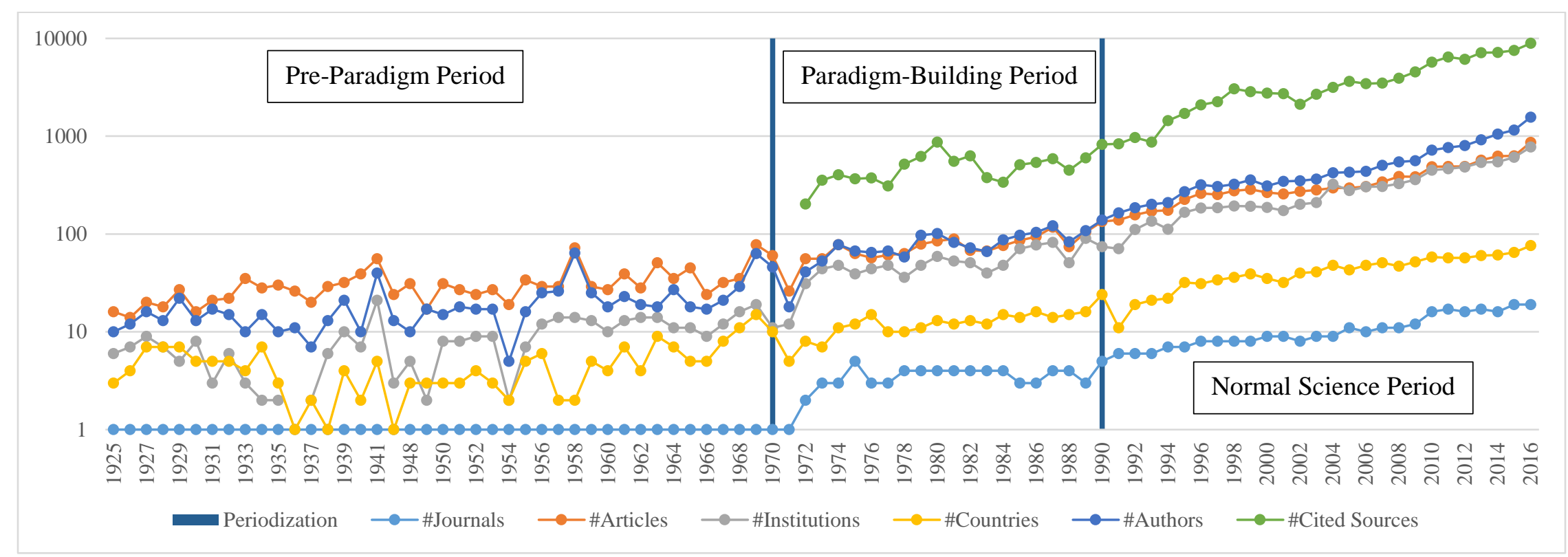


Figure 6. Number of papers published in the three journals serving nonprofit and philanthropic studies dedicatedly (i.e., NML/NVSQ/Voluntas).

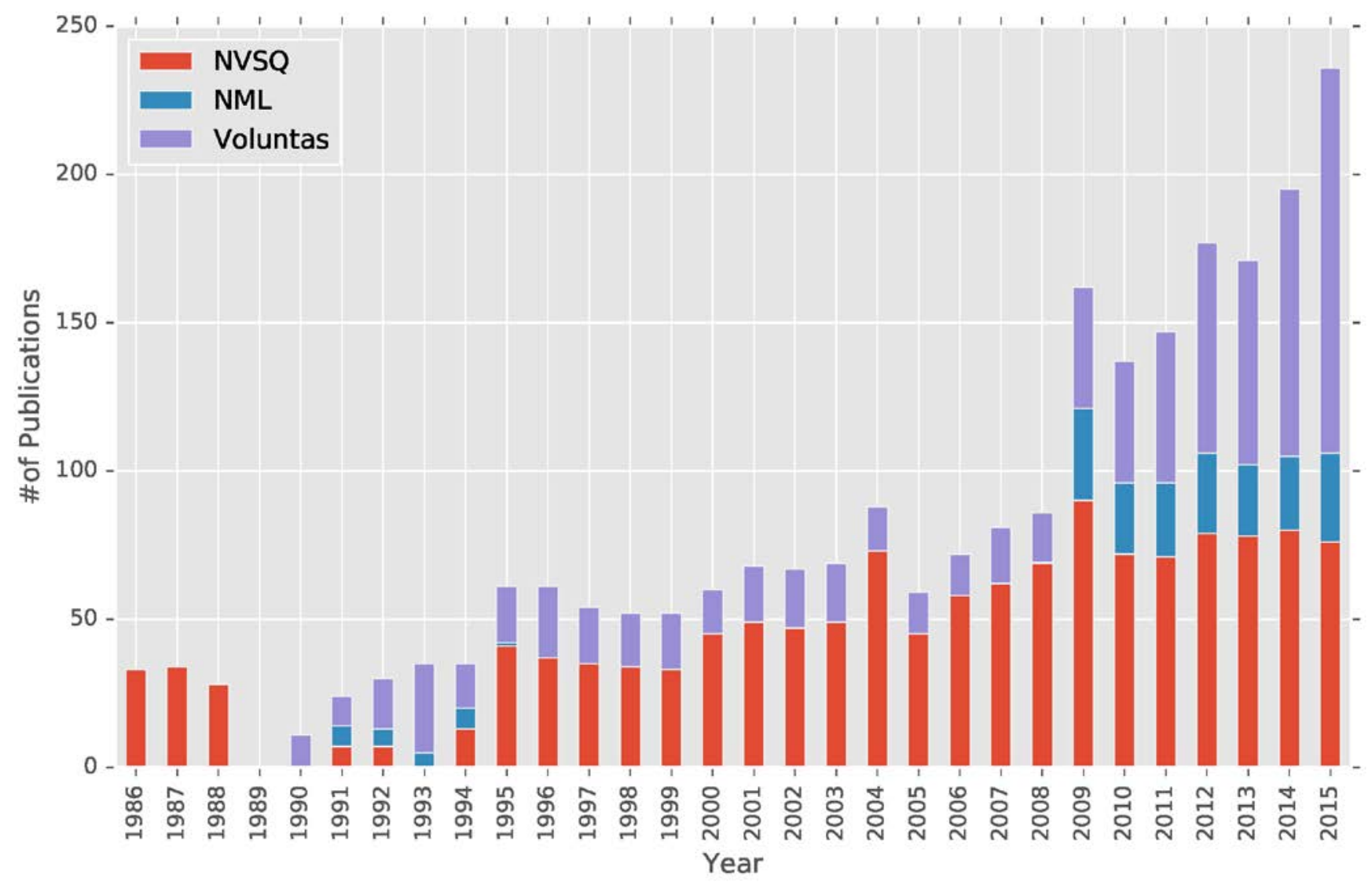

Note: $N M L=$ Nonprofit and Management Leadership; NVSQ / JVAR = Nonprofit and Voluntary Sector Quarterly / Journal of Voluntary Action Research. Records of 1989 and NML records between 1995-2008 are missing from all data sources. 
Figure 7. Paper distribution by country according to author’s affiliation (1986-2015).

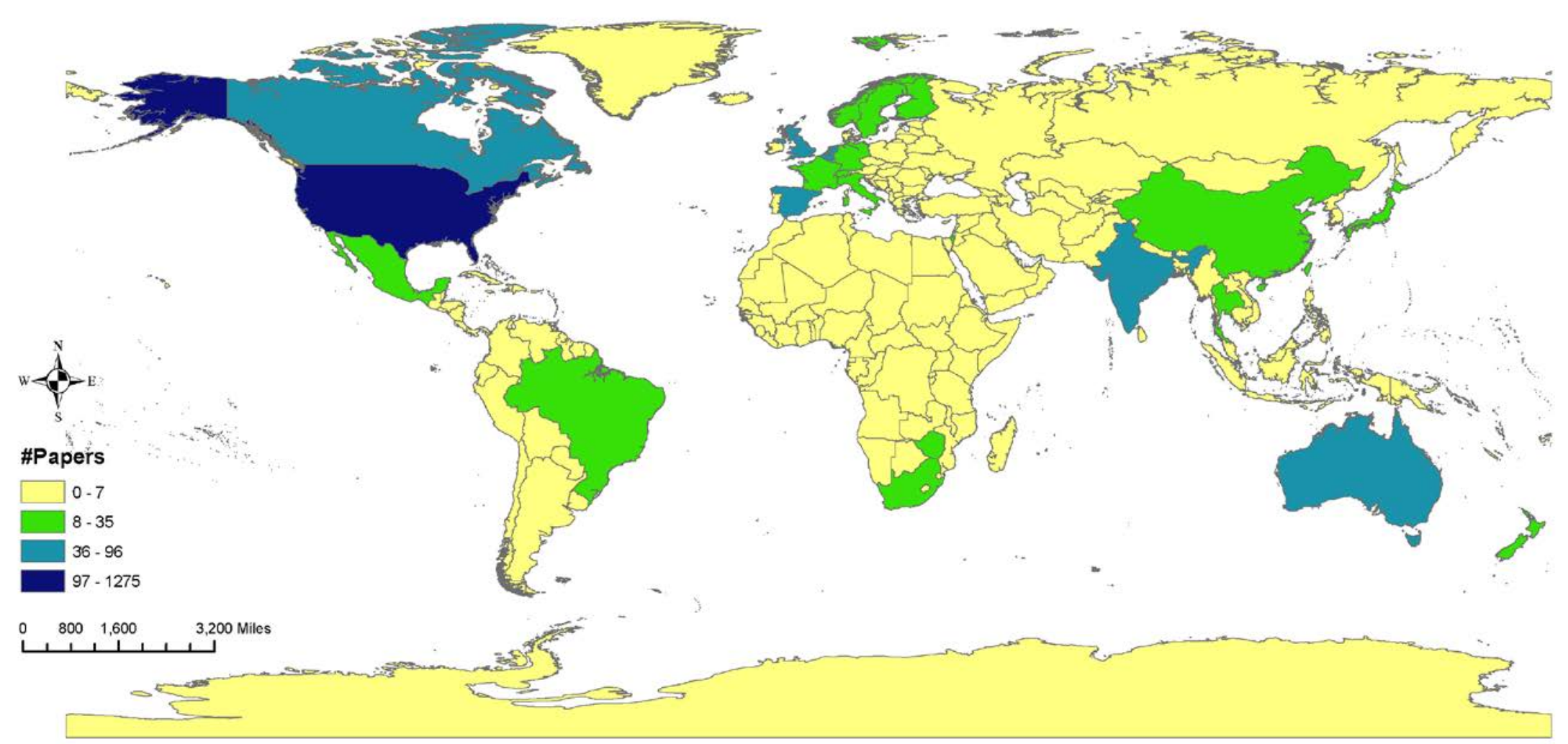

Note: The authors remain neutral regarding jurisdictional claims in maps. 
Figure 8. Four major bibliographic networks.
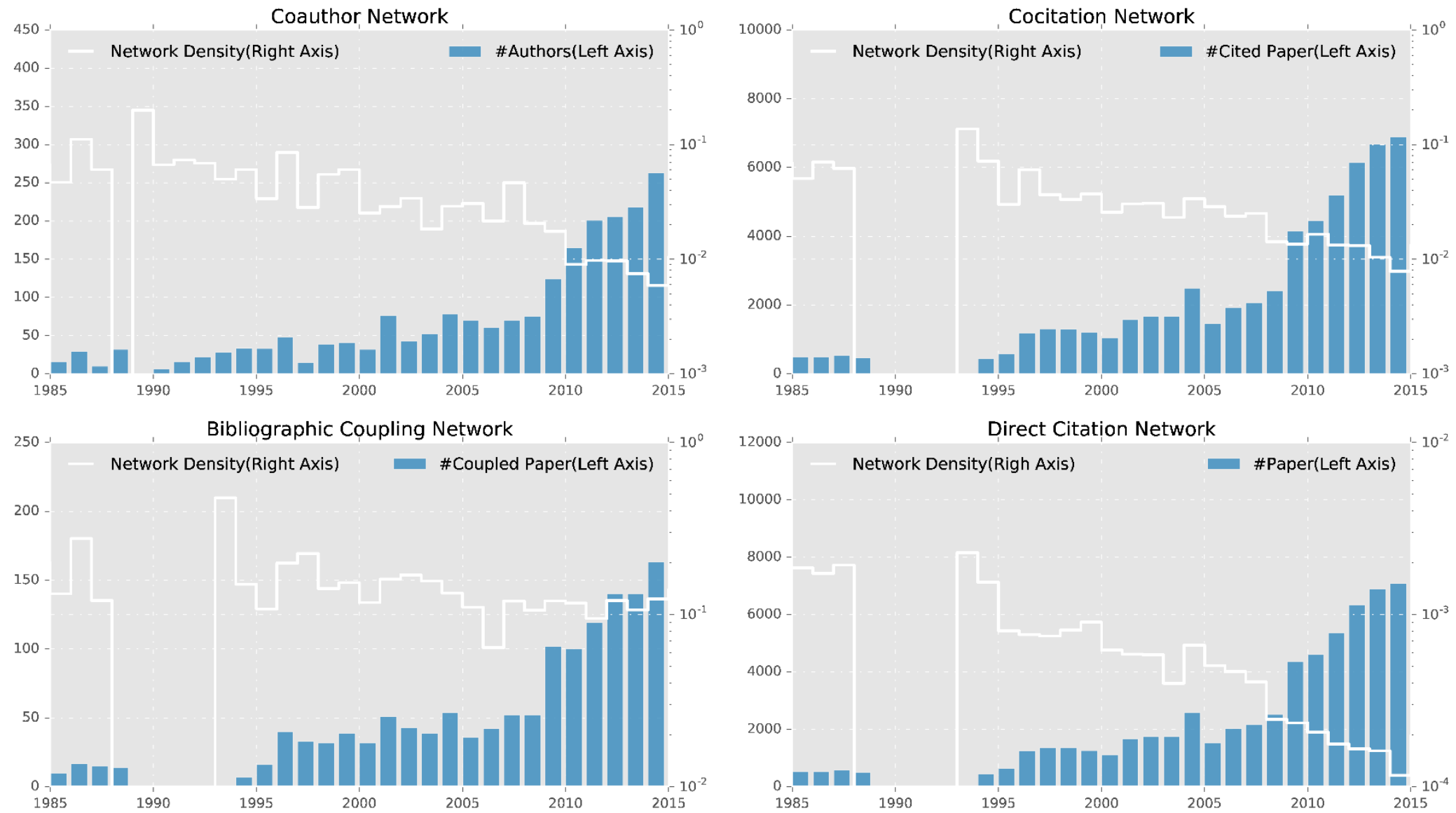

Note: For each year, a corresponding network in that year is constructed and the metrics show the profile of the network of that year. 
Figure 9. Clusters in the co-citation network and citation counts.

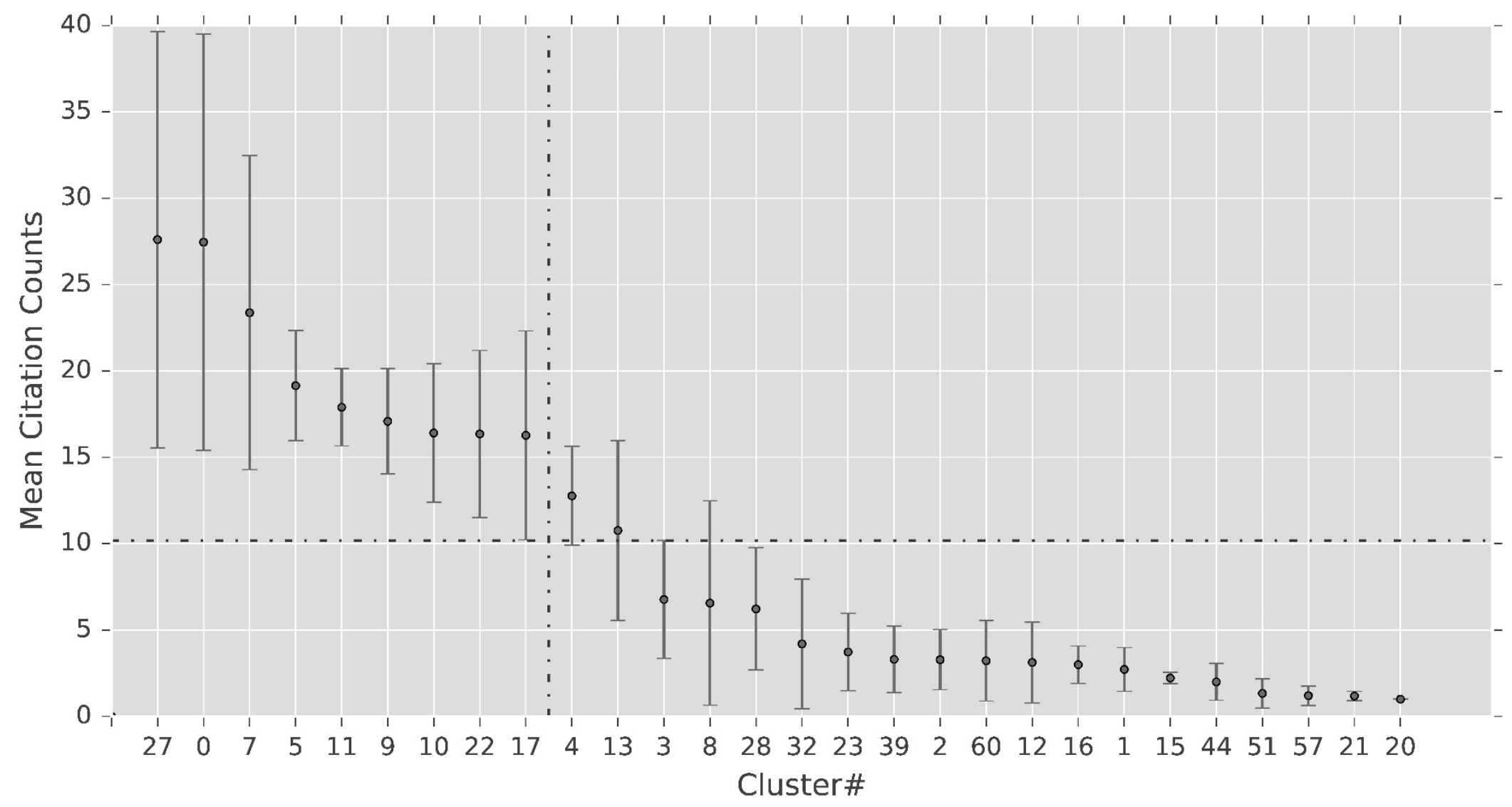

Note: Error bars show 95\% confidence intervals. Clusters above the reference line are identified as the major topics in nonprofit and philanthropic studies. The cluster number is determined by computer program and not renamed to consistently present findings with raw data posted online. See detail methodology http://bit.ly/30npo. 
Figure 10. Network visualization by clusters and topology of disciplines.

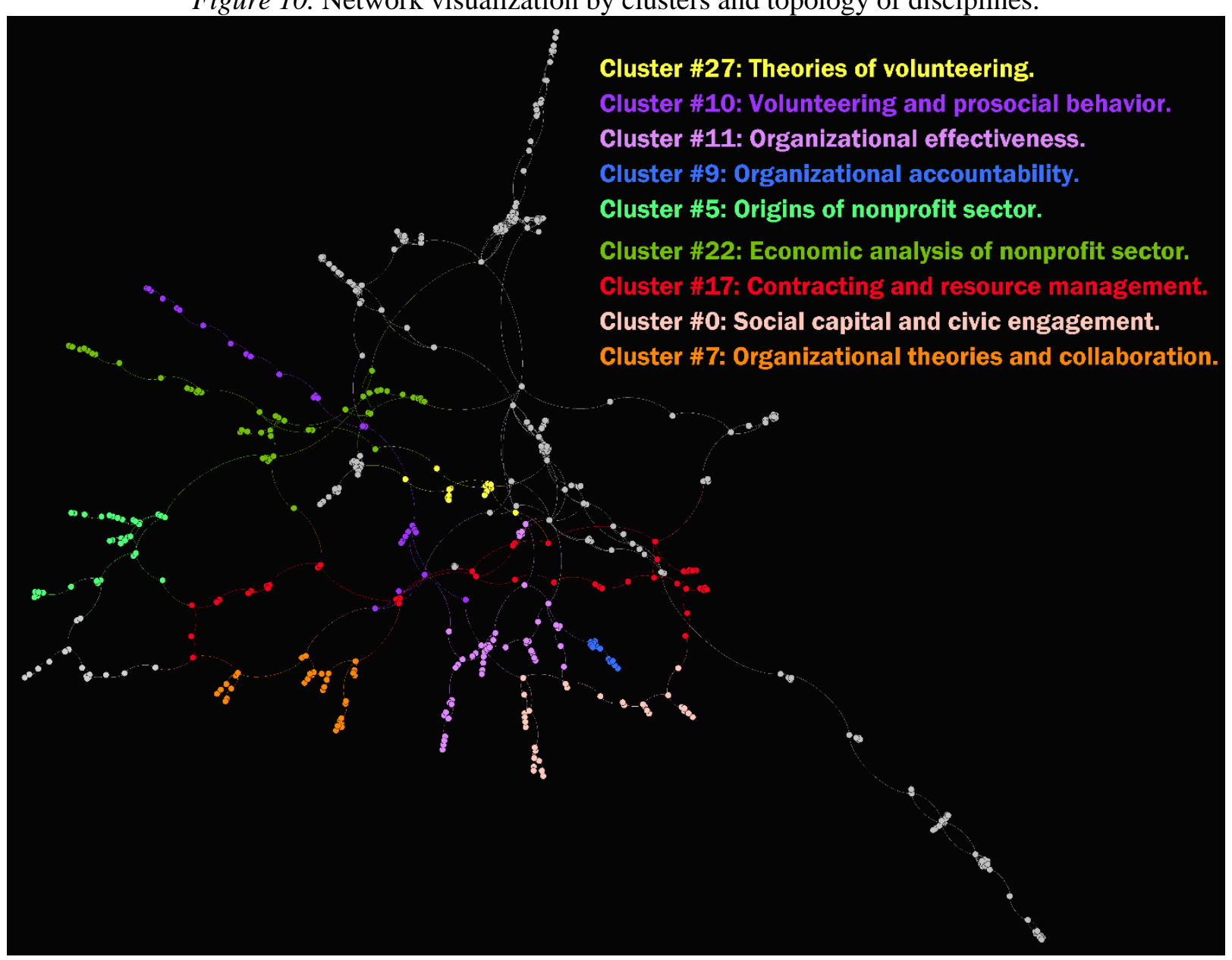

Note: The cluster number is determined by computer program and not renamed to consistently present findings with raw data posted online. See detail methodology http://bit.ly/30npo. 
Figure 11: Mean attachment probability of major topics by year.
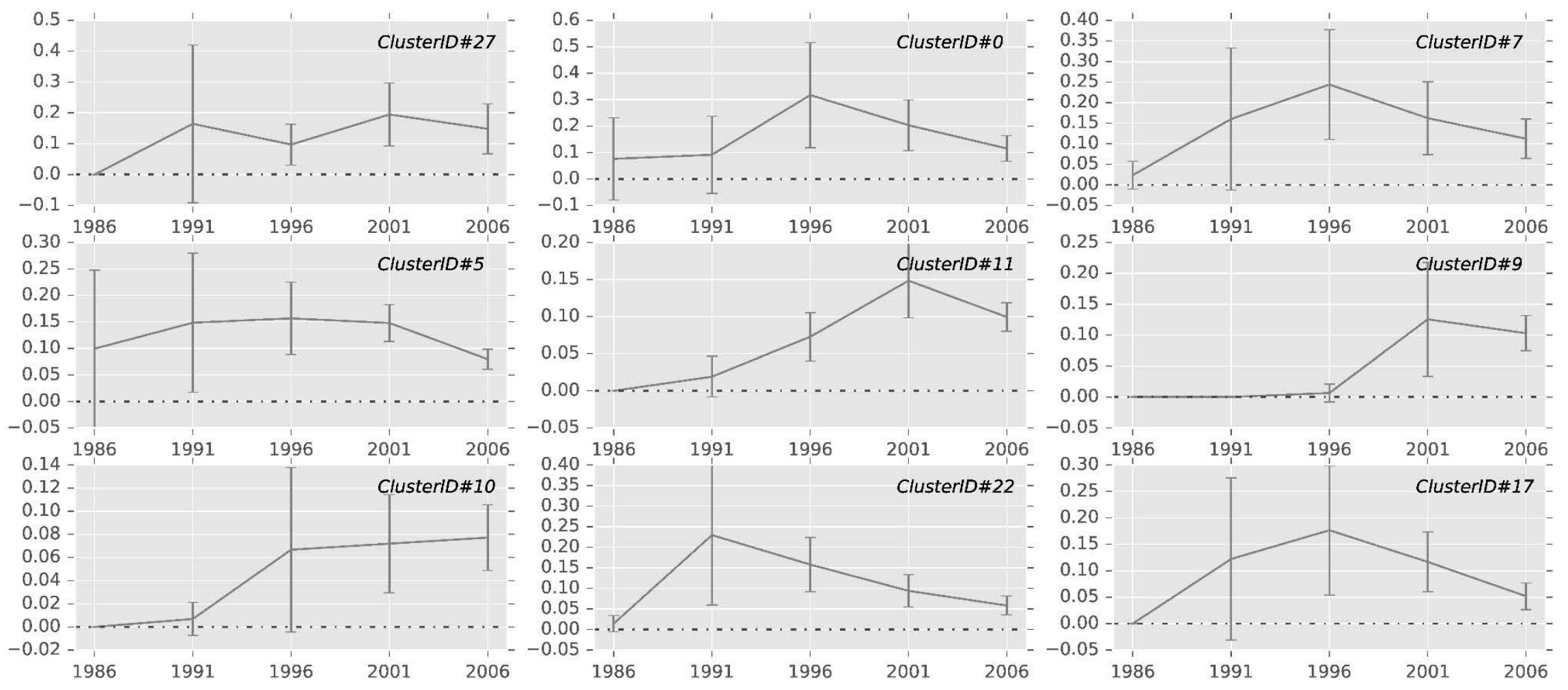

Note: Error bars show 95\% confidence intervals. Y-scale multiplied by 100 for visual clarity. The cluster number is determined by computer program and not renamed to consistently present findings with raw data posted online. See detail methodology http://bit.ly/30npo. 
Table 1. Dataset for analysis.

\begin{tabular}{cccc}
\hline \hline Journals & NVSQ / JVAR & Voluntas & NML \\
\hline Range of Total Publication & $1972: 1(1)-2016: 45(3)$ & $1990: 1(1)-2016: 27(3)$ & $1990: 1(1)-2016: 27(3)$ \\
& & & \\
\hline Range of Records in Dataset & $1972: 1(1)-2016: 45(3)$ & $1990: 1(1)-2016: 27(3)$ & $1991: 2(1)-1995: 6(1)$ \\
& & & $2009: 19(3)-2016: 26(3)$ \\
\hline \#of Records in Dataset & 1730 & 900 & 218
\end{tabular}

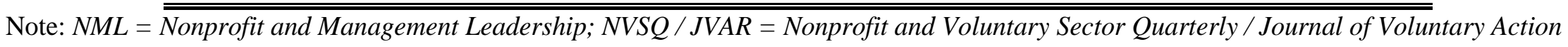
Research. The data of NML in 1990 and between 1996-2008 is not available from the two data sources (i.e., Web of Science and Scopus). 
Table 2. Top 20 institutions in nonprofit studies by the number of papers produced.

\begin{tabular}{|c|c|c|c|c|}
\hline Country & Institution & $\begin{array}{r}\# \\
\text { Articles }\end{array}$ & $\begin{array}{r}\# \\
\text { Authors }\end{array}$ & $\begin{array}{r}\text { \#Papers } \\
\text { per Author }\end{array}$ \\
\hline United States & Indiana University & 153 & 119 & 1.29 \\
\hline United States & Harvard University & 139 & 135 & 1.03 \\
\hline Belgium & Universite de Liege & 105 & 56 & 1.88 \\
\hline Australia & University of Queensland & 103 & 63 & 1.63 \\
\hline United States & Yale University & 74 & 51 & 1.45 \\
\hline United States & University of Southern California & 74 & 47 & 1.57 \\
\hline $\begin{array}{l}\text { United } \\
\text { Kingdom }\end{array}$ & $\begin{array}{l}\text { London School of Economics and Political } \\
\text { Science }\end{array}$ & 64 & 54 & 1.19 \\
\hline United States & University of Pennsylvania & 61 & 33 & 1.85 \\
\hline United States & Columbia University in the City of New York & 58 & 43 & 1.35 \\
\hline France & Universite Paris 1 Pantheon-Sorbonne & 57 & 45 & 1.27 \\
\hline United States & Stanford University & 54 & 45 & 1.20 \\
\hline Australia & Griffith University & 48 & 49 & 0.98 \\
\hline China & Tsinghua University & 47 & 49 & 0.96 \\
\hline United States & The University of Georgia & 46 & 30 & 1.53 \\
\hline United States & UC Berkeley & 44 & 40 & 1.10 \\
\hline Israel & Hebrew University of Jerusalem & 44 & 31 & 1.42 \\
\hline United States & Georgia State University & 43 & 37 & 1.16 \\
\hline United States & New York University & 43 & 38 & 1.13 \\
\hline United States & $\begin{array}{l}\text { Virginia Polytechnic Institute and State } \\
\text { University }\end{array}$ & 42 & 41 & 1.02 \\
\hline United States & Johns Hopkins University & 42 & 20 & 2.10 \\
\hline
\end{tabular}

Note: Indiana University-Purdue University Indianapolis and Harvard Law School are merged with Indiana University and Harvard University respectively. 
Table 3. Major topics by general analytical categories.

\begin{tabular}{|c|c|c|c|c|}
\hline Human/financial resources & Effectiveness/performance & $\begin{array}{l}\text { Organization } \\
\text { development }\end{array}$ & $\begin{array}{l}\text { Intra-organization } \\
\text { context }\end{array}$ & 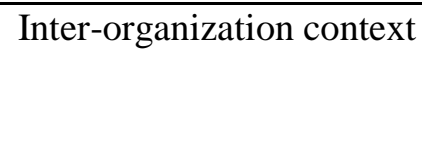 \\
\hline $\begin{array}{l}\text { Cluster \#27: Theories of } \\
\text { volunteering }\end{array}$ & $\begin{array}{l}\text { Cluster \#11: Organizational } \\
\text { effectiveness }\end{array}$ & $\begin{array}{l}\text { Cluster \#5: Origins of } \\
\text { nonprofit sector }\end{array}$ & $\begin{array}{l}\text { Cluster \#17: } \\
\text { Contracting and } \\
\text { resource management }\end{array}$ & $\begin{array}{l}\text { Cluster \#0: Social capital } \\
\text { and civic engagement }\end{array}$ \\
\hline $\begin{array}{l}\text { Cluster \#10: Volunteering } \\
\text { and pro-social behavior }\end{array}$ & $\begin{array}{l}\text { Cluster \#9: Organizational } \\
\text { accountability }\end{array}$ & $\begin{array}{l}\text { Cluster \#22: Economic } \\
\text { analysis of nonprofit } \\
\text { sector }\end{array}$ & & $\begin{array}{l}\text { Cluster \#7: } \\
\text { Organizational theories } \\
\text { and collaboration }\end{array}$ \\
\hline
\end{tabular}

Note: Analytical categories introduced by Shier and Handy (2014, p. 816). 
Table 4. Top 5 most cited references in Cluster \#27: Theories of volunteering.

\begin{tabular}{|c|c|c|c|c|c|}
\hline $\begin{array}{l}\text { Citation } \\
\text { Counts }\end{array}$ & $\begin{array}{l}\text { First } \\
\text { Author }\end{array}$ & Year & Title & Source & Article Key Theme \\
\hline 64 & Wilson J & 2000 & Volunteering & $\begin{array}{l}\text { Annual Review of } \\
\text { Sociology }\end{array}$ & $\begin{array}{l}\text { Literature review of theories } \\
\text { of volunteering }\end{array}$ \\
\hline 47 & Smith DH & 1994 & $\begin{array}{l}\text { Determinants of voluntary association } \\
\text { participation and volunteering: A literature } \\
\text { review }\end{array}$ & $\begin{array}{l}\text { Nonprofit and Voluntary } \\
\text { Sector Quarterly }\end{array}$ & $\begin{array}{l}\text { Literature review of } \\
\text { predictors for volunteering }\end{array}$ \\
\hline 42 & Wilson J & 1997 & $\begin{array}{l}\text { Who cares? Toward an integrated theory of } \\
\text { volunteer work }\end{array}$ & $\begin{array}{l}\text { American Sociological } \\
\text { Review }\end{array}$ & $\begin{array}{l}\text { Empirical study on theory of } \\
\text { volunteering }\end{array}$ \\
\hline 30 & $\begin{array}{l}\text { Musick } \\
\text { MA }\end{array}$ & 2008 & Volunteering: A social profile & Book & $\begin{array}{l}\text { Book on volunteering } \\
\text { theories and influencers }\end{array}$ \\
\hline 38 & Andreoni $\mathrm{J}$ & 1990 & $\begin{array}{l}\text { Impure Altruism and Donations to Public } \\
\text { Goods: A Theory of Warm-Glow Giving }\end{array}$ & The Economic Journal & $\begin{array}{l}\text { Economic analysis of } \\
\text { volunteering motivation }\end{array}$ \\
\hline
\end{tabular}

Note: Citation counts represent the number of times that the papers are cited by all the other articles in Dataset 2. 
Table 5. Top 5 most cited references in Cluster \#0: Social capital and civic engagement.

\begin{tabular}{|c|c|c|c|c|c|}
\hline Citation Counts & $\begin{array}{l}\text { First } \\
\text { Author }\end{array}$ & Year & Title & Source & Article Key Theme \\
\hline 150 & $\begin{array}{l}\text { Putnam } \\
\text { RD }\end{array}$ & 2000 & $\begin{array}{l}\text { Bowling Alone: The Collapse and Revival } \\
\text { of American Community }\end{array}$ & Book & $\begin{array}{l}\text { Declining social capital } \\
\text { in America }\end{array}$ \\
\hline 98 & $\begin{array}{l}\text { Putnam } \\
\text { RD }\end{array}$ & 1993 & $\begin{array}{l}\text { Making Democracy Work: Civic Traditions } \\
\text { in Modern Italy }\end{array}$ & Book & $\begin{array}{l}\text { Book on civic } \\
\text { participation }\end{array}$ \\
\hline 55 & $\begin{array}{l}\text { Putnam } \\
\text { RD }\end{array}$ & 1995 & $\begin{array}{l}\text { Bowling Alone: America's Declining Social } \\
\text { Capital }\end{array}$ & Journal of Democracy & $\begin{array}{l}\text { Declining social capital } \\
\text { in America }\end{array}$ \\
\hline 34 & $\begin{array}{l}\text { Coleman } \\
\text { JS }\end{array}$ & 1988 & $\begin{array}{l}\text { Social Capital in the Creation of Human } \\
\text { Capital }\end{array}$ & $\begin{array}{l}\text { The American Journal } \\
\text { of Sociology }\end{array}$ & $\begin{array}{l}\text { Early classic article on } \\
\text { social capital }\end{array}$ \\
\hline 28 & Glaser B & 1967 & $\begin{array}{l}\text { The Discovery of Grounded Theory: } \\
\text { Strategies for Qualitative Research }\end{array}$ & Book & Grounded theory Method \\
\hline
\end{tabular}


Table 6. Top 5 most cited references in Cluster \#7: Organizational theories and collaboration.

\begin{tabular}{|c|c|c|c|c|c|}
\hline Citation Counts & $\begin{array}{l}\text { First } \\
\text { Author }\end{array}$ & Year & Title & Source & Article Key Theme \\
\hline 125 & $\begin{array}{l}\text { DiMaggio } \\
\text { PJ }\end{array}$ & 1983 & $\begin{array}{l}\text { The Iron Cage Revisited: Institutional } \\
\text { Isomorphism and Collective Rationality } \\
\text { in Organizational Fields }\end{array}$ & $\begin{array}{l}\text { American Sociological } \\
\text { Review }\end{array}$ & $\begin{array}{l}\text { Classic article establishing new } \\
\text { institutionalism }\end{array}$ \\
\hline 91 & Pfeffer J & 1978 & $\begin{array}{l}\text { The External Control of Organizations: } \\
\text { A Resource Dependence Perspective }\end{array}$ & Book & $\begin{array}{l}\text { Classic book establishing } \\
\text { resource dependence theory }\end{array}$ \\
\hline 64 & Meyer JW & 1977 & $\begin{array}{l}\text { Institutionalized Organizations: Formal } \\
\text { Structure as Myth and Ceremony }\end{array}$ & $\begin{array}{l}\text { American Journal of } \\
\text { Sociology }\end{array}$ & $\begin{array}{l}\text { Classic article on } \\
\text { institutionalism }\end{array}$ \\
\hline 40 & $\begin{array}{l}\text { Eikenberry } \\
\text { AM }\end{array}$ & 2004 & $\begin{array}{l}\text { The Marketization of the Nonprofit } \\
\text { Sector: Civil Society at Risk? }\end{array}$ & $\begin{array}{l}\text { Public Administration } \\
\text { Review }\end{array}$ & $\begin{array}{l}\text { Review article on the impact of } \\
\text { nonprofit marketization on civil } \\
\text { society }\end{array}$ \\
\hline 28 & Austin JE & 2000 & $\begin{array}{l}\text { Strategic Collaboration Between } \\
\text { Nonprofits and Business }\end{array}$ & $\begin{array}{l}\text { Nonprofit and } \\
\text { Voluntary Sector } \\
\text { Quarterly }\end{array}$ & $\begin{array}{l}\text { Qualitative empirical study on } \\
\text { cross-sector collaboration } \\
\text { framework }\end{array}$ \\
\hline
\end{tabular}


Table 7. Top 5 most cited references in Cluster \#5: Origins of nonprofit sector.

\begin{tabular}{|c|c|c|c|c|c|}
\hline Citation Counts & $\begin{array}{l}\text { First } \\
\text { Author }\end{array}$ & Year & Title & Source & Article Key Theme \\
\hline 74 & Salamon LM & 1995 & $\begin{array}{l}\text { Partners in Public Service: } \\
\text { Government-Nonprofit Relations in } \\
\text { the Modern Welfare State }\end{array}$ & Book & $\begin{array}{l}\text { Book on government-nonprofit } \\
\text { relationship }\end{array}$ \\
\hline 54 & Salamon LM & 1987 & $\begin{array}{l}\text { Partners in Public Service: The } \\
\text { Scope and Theory of Government- } \\
\text { Nonprofit Relations }\end{array}$ & $\begin{array}{l}\text { The Nonprofit } \\
\text { Sector: A Research } \\
\text { Handbook }\end{array}$ & $\begin{array}{l}\text { Book chapter on government- } \\
\text { nonprofit relationship }\end{array}$ \\
\hline 48 & Salamon LM & 1998 & $\begin{array}{l}\text { Social Origins of Civil Society: } \\
\text { Explaining the Nonprofit Sector } \\
\text { Cross-Nationally }\end{array}$ & Voluntas & $\begin{array}{l}\text { Empirical quantitative and cross- } \\
\text { nation study on theories explaining } \\
\text { the origins of nonprofit sector }\end{array}$ \\
\hline 37 & $\begin{array}{l}\text { DiMaggio } \\
\text { PJ }\end{array}$ & 1990 & $\begin{array}{l}\text { The Sociology of Nonprofit } \\
\text { Organizations and Sectors }\end{array}$ & $\begin{array}{l}\text { Annual Review of } \\
\text { Sociology }\end{array}$ & $\begin{array}{l}\text { Review of the theories explaining the } \\
\text { existence of nonprofit sector from } \\
\text { sociological perspective }\end{array}$ \\
\hline 36 & $\begin{array}{l}\text { Esping- } \\
\text { Andersen G }\end{array}$ & 1990 & $\begin{array}{l}\text { The Three Worlds of Welfare } \\
\text { Capitalism }\end{array}$ & Book & Typology of welfare states \\
\hline
\end{tabular}


Table 8. Top 5 most cited references in Cluster \#9: Organizational accountability.

\begin{tabular}{|c|c|c|c|c|c|}
\hline Citation Counts & $\begin{array}{l}\text { First } \\
\text { Author }\end{array}$ & Year & Title & Source & Article Key Theme \\
\hline 26 & $\begin{array}{l}\text { Ebrahim } \\
\text { A }\end{array}$ & 2005 & $\begin{array}{l}\text { Accountability Myopia: Losing Sight } \\
\text { of Organizational Learning }\end{array}$ & $\begin{array}{l}\text { Nonprofit and } \\
\text { Voluntary Sector } \\
\text { Quarterly }\end{array}$ & $\begin{array}{l}\text { Conceptual article on introducing } \\
\text { organizational learning to } \\
\text { accountability }\end{array}$ \\
\hline 23 & $\begin{array}{l}\text { Ebrahim } \\
\text { A }\end{array}$ & 2003 & $\begin{array}{l}\text { Accountability In Practice: } \\
\text { Mechanisms for NGOs }\end{array}$ & $\begin{array}{l}\text { Accountability In } \\
\text { Practice: Mechanisms } \\
\text { for NGOs }\end{array}$ & $\begin{array}{l}\text { How nonprofits practice } \\
\text { accountability }\end{array}$ \\
\hline 21 & Ospina S & 2002 & $\begin{array}{l}\text { Negotiating Accountability: } \\
\text { Managerial Lessons from Identity- } \\
\text { Based Nonprofit Organizations }\end{array}$ & $\begin{array}{l}\text { Nonprofit and } \\
\text { Voluntary Sector } \\
\text { Quarterly }\end{array}$ & $\begin{array}{l}\text { Qualitative empirical study } \\
\text { broadening the traditional concept of } \\
\text { accountability in nonprofits }\end{array}$ \\
\hline 19 & $\begin{array}{l}\text { Edwards } \\
\text { M }\end{array}$ & 1996 & $\begin{array}{l}\text { Beyond the Magic Bullet: NGO } \\
\text { Performance and Accountability in } \\
\text { the Post-Cold War World }\end{array}$ & Book & $\begin{array}{l}\text { Early work defining and examining } \\
\text { accountability in nonprofits }\end{array}$ \\
\hline 18 & $\begin{array}{l}\text { Brown } \\
\text { LD }\end{array}$ & 2001 & $\begin{array}{l}\text { Accountability, Strategy, and } \\
\text { International Nongovernmental } \\
\text { Organizations }\end{array}$ & $\begin{array}{l}\text { Nonprofit and } \\
\text { Voluntary Sector } \\
\text { Quarterly }\end{array}$ & $\begin{array}{l}\text { Conceptual article on developing } \\
\text { accountability in international } \\
\text { nongovernmental organizations }\end{array}$ \\
\hline
\end{tabular}


Table 9. Top 10 references in the co-citation network by betweenness centrality.

\begin{tabular}{|c|c|c|c|c|c|c|c|c|}
\hline$\#$ & Topic & $\begin{array}{c}\text { Betweenness } \\
\text { Centrality }\end{array}$ & $\begin{array}{l}\text { Citation } \\
\text { Counts }\end{array}$ & $\begin{array}{l}\text { 1st Author } \\
\text { Surname }\end{array}$ & Year & Reference Title & Source Title & Journals Mostly Citing \\
\hline 1 & $\begin{array}{l}\text { Prosocial } \\
\text { behavior and } \\
\text { volunteering }\end{array}$ & 0.81 & 186 & Einolf & 2008 & $\begin{array}{l}\text { Empathetic concern and } \\
\text { prosocial behaviors: A test } \\
\text { of experimental results } \\
\text { using survey data }\end{array}$ & $\begin{array}{l}\text { Social Science } \\
\text { Research }\end{array}$ & $\begin{array}{l}\text { Nonprofit and Voluntary Sector } \\
\text { Quarterly } \\
\text { Voluntas } \\
\text { European Sociological Review } \\
\text { Ageing and Society }\end{array}$ \\
\hline 2 & $\begin{array}{l}\text { Volunteering and } \\
\text { political } \\
\text { participation }\end{array}$ & 0.31 & 226 & McFarland & 2006 & $\begin{array}{l}\text { Bowling young: How } \\
\text { youth voluntary } \\
\text { associations influence } \\
\text { adult political participation }\end{array}$ & $\begin{array}{l}\text { American } \\
\text { Sociological } \\
\text { Review }\end{array}$ & $\begin{array}{l}\text { American Journal of Sociology } \\
\text { American Sociological Review } \\
\text { Nonprofit and Voluntary Sector } \\
\text { Quarterly }\end{array}$ \\
\hline 3 & Volunteering & 0.30 & 1,754 & Musick & 2008 & $\begin{array}{l}\text { Volunteers: A Social } \\
\text { Profile }\end{array}$ & Book & $\begin{array}{l}\text { Nonprofit and Voluntary Sector } \\
\text { Quarterly } \\
\text { Journal for the Scientific Study } \\
\text { of Religion } \\
\text { Leisure Sciences } \\
\text { American Sociological Review }\end{array}$ \\
\hline 4 & Volunteering & 0.24 & 859 & Cnaan & 1996 & $\begin{array}{l}\text { Defining who is a } \\
\text { volunteer: Conceptual and } \\
\text { empirical considerations }\end{array}$ & $\begin{array}{l}\text { Nonprofit and } \\
\text { Voluntary } \\
\text { Sector } \\
\text { Quarterly }\end{array}$ & $\begin{array}{l}\text { Nonprofit and Voluntary Sector } \\
\text { Quarterly } \\
\text { Journal for the Scientific Study } \\
\text { of Religion } \\
\text { Nonprofit Management and } \\
\text { Leadership }\end{array}$ \\
\hline 5 & $\begin{array}{l}\text { Organizational } \\
\text { theory }\end{array}$ & 0.24 & 49 & Hannan & 1987 & $\begin{array}{l}\text { The ecology of } \\
\text { organizational founding: } \\
\text { American labor unions, } \\
\text { 1836-1985 }\end{array}$ & $\begin{array}{l}\text { American } \\
\text { Journal of } \\
\text { Sociology }\end{array}$ & $\begin{array}{l}\text { Nonprofit and Voluntary Sector } \\
\text { Quarterly } \\
\text { Nonprofit Management and } \\
\text { Leadership } \\
\text { American Journal of Sociology } \\
\text { Administrative Science } \\
\text { Quarterly }\end{array}$ \\
\hline
\end{tabular}




\begin{tabular}{|c|c|c|c|c|c|c|c|c|}
\hline 6 & $\begin{array}{l}\text { Organizational } \\
\text { theory }\end{array}$ & 0.23 & 1,532 & Meyer & 1977 & $\begin{array}{l}\text { Institutionalized } \\
\text { Organizations: Formal } \\
\text { Structure as Myth and } \\
\text { Ceremony }\end{array}$ & $\begin{array}{l}\text { American } \\
\text { Journal of } \\
\text { Sociology }\end{array}$ & $\begin{array}{l}\text { American Sociological Review } \\
\text { Journal of Economic Growth } \\
\text { Journal of Development } \\
\text { Economics }\end{array}$ \\
\hline 7 & Volunteering & 0.22 & 257 & Van Ingen & 2011 & $\begin{array}{l}\text { Changes in the } \\
\text { determinants of } \\
\text { volunteering: Participation } \\
\text { and time investment } \\
\text { between } 1975 \text { and } 2005 \text { in } \\
\text { the Netherlands }\end{array}$ & $\begin{array}{l}\text { Nonprofit and } \\
\text { Voluntary } \\
\text { Sector } \\
\text { Quarterly }\end{array}$ & $\begin{array}{l}\text { Nonprofit and Voluntary Sector } \\
\text { Quarterly } \\
\text { Social Forces } \\
\text { Social Science and Medicine } \\
\text { American Journal of Sociology }\end{array}$ \\
\hline 8 & $\begin{array}{l}\text { Political and } \\
\text { civic } \\
\text { participation }\end{array}$ & 0.21 & 896 & Olson & 1965 & $\begin{array}{l}\text { The Logic of Collective } \\
\text { Action }\end{array}$ & Book & $\begin{array}{l}\text { American Sociological Review } \\
\text { American Journal of Sociology } \\
\text { Annals of Public and } \\
\text { Cooperative Economics }\end{array}$ \\
\hline 9 & Political system & 0.16 & 1,056 & Levitsky & 2002 & $\begin{array}{l}\text { The rise of competitive } \\
\text { authoritarianism }\end{array}$ & $\begin{array}{l}\text { Journal of } \\
\text { Democracy }\end{array}$ & $\begin{array}{l}\text { Democratization } \\
\text { Journal of Democracy } \\
\text { Comparative Politics }\end{array}$ \\
\hline 10 & $\begin{array}{l}\text { Political and } \\
\text { civic } \\
\text { participation }\end{array}$ & 0.16 & 870 & Tocqueville & 1961 & Democracy in America & Book & $\begin{array}{l}\text { American Sociological Review } \\
\text { Journal of Democracy } \\
\text { Democratization }\end{array}$ \\
\hline
\end{tabular}




\section{REFERENCES}

Adams, W. C., Lind Infeld, D., Wikrent, K. L., \& Bintou Cisse, O. (2016). Network Bibliometrics of Public Policy Journals. Policy Studies Journal, 44(S1), S133-S151. https://doi.org/10.1111/psj.12149

Anheier, H. K., \& Ben-Ner, A. (1997). Economic Theories of Non-Profit Organisations: A Voluntas Symposium. Voluntas: International Journal of Voluntary and Nonprofit Organizations, 8(2), 93-96.

Austin, J. E. (2000). Strategic Collaboration Between Nonprofits and Business. Nonprofit and Voluntary Sector Quarterly, 29(suppl 1), 69-97. https://doi.org/10.1177/089976400773746346

Benjamin, L. M. (2008). Account Space: How Accountability Requirements Shape Nonprofit Practice. Nonprofit and Voluntary Sector Quarterly, 37(2), 201-223. https://doi.org/10.1177/0899764007301288

Bennett, J. C. (2007). The Anglosphere Challenge: Why the English-speaking Nations Will Lead the Way in the Twenty-first Century. Rowman \& Littlefield.

Bernick, E., \& Krueger, S. (2010). An Assessment of Journal Quality in Public Administration. International Journal of Public Administration, 33(2), 98-106. https://doi.org/10.1080/01900690903188891

Börner, K., Theriault, T. N., \& Boyack, K. W. (2015). Mapping science introduction: Past, present and future. Bulletin of the American Society for Information Science and Technology, 41(2), 12-16. https://doi.org/10.1002/bult.2015.1720410205

Brass, J. N., Longhofer, W., Robinson, R. S., \& Schnable, A. (2018). NGOs and international development: A review of thirty-five years of scholarship. World Development, 112, 136-149. https://doi.org/10.1016/j.worlddev.2018.07.016

Bremner, R. H. (1988). American philanthropy (2nd ed). Chicago: University of Chicago Press.

Brudney, J. L., \& Durden, T. K. (1993). Twenty Years of the Journal of Voluntary Action Research/Nonprofit and Voluntary Sector Quarterly An Assessment of Past Trends and Future Directions. Nonprofit and Voluntary Sector Quarterly, 22(3), 207-218. https://doi.org/10.1177/0899764093223004

Brudney, J. L., \& Herman, R. D. (2004). Readers’ Perceptions of Philanthropy and Nonprofit Management Journals. The American Review of Public Administration, 34(3), 293-301. https://doi.org/10.1177/0275074004266326

Brudney, J. L., \& Kluesner, T. M. (1992). Researchers and Practitioners in Nonprofit Organization and Voluntary Action: Applying Research to Practice? Nonprofit and Voluntary Sector Quarterly, 21(3), 293-308. https://doi.org/10.1177/089976409202100307

Burt, R. S. (1992). Structural holes: the social structure of competition. Cambridge, Mass: Harvard University Press.

Bushouse, B. K., \& Sowa, J. E. (2012). Producing Knowledge For Practice Assessing NVSQ 2000-2010. Nonprofit and Voluntary Sector Quarterly, 41(3), 497-513. https://doi.org/10.1177/0899764011422116

Carrington, P. J., \& Scott, J. (2011). Introduction. In J. Scott \& P. Carrington, The SAGE Handbook of Social Network Analysis (pp. 1-8). 1 Oliver's Yard, 55 City Road, London EC1Y 1SP United Kingdom: SAGE Publications Ltd. Retrieved from http://srmo.sagepub.com/view/the-sage-handbook-of-social-network-analysis/n1.xml

Chen, C. (2006). CiteSpace II: Detecting and visualizing emerging trends and transient patterns in scientific literature. Journal of the American Society for Information Science and Technology, 57(3), 359-377. https://doi.org/10.1002/asi.20317

Chen, C. (2014). The CiteSpace Manual (Version 1.01). College of Computing and Informatics Drexel University. 
Clemens, E. (2006). The Constitution of Citizens: Political Theories of Nonprofit Organizations. In W. W. Powell \& R. Steinberg (Eds.), The nonprofit sector: A research handbook (pp. 207-220). Yale University Press.

Cobo, M. j., López-Herrera, A. g., Herrera-Viedma, E., \& Herrera, F. (2011). Science mapping software tools: Review, analysis, and cooperative study among tools. Journal of the American Society for Information Science and Technology, 62(7), 1382-1402. https://doi.org/10.1002/asi.21525

Coleman, J. S. (1988). Social Capital in the Creation of Human Capital. American Journal of Sociology, 94, S95-S120.

Corry, O. (2010). Defining and Theorizing the Third Sector. In R. Taylor (Ed.), Third Sector Research (pp. 11-20). New York, NY: Springer New York. Retrieved from http://link.springer.com/10.1007/978-1-4419-5707-8_2

DiMaggio, P. J., \& Anheier, H. K. (1990). The Sociology of Nonprofit Organizations and Sectors. Annual Review of Sociology, 16, 137-159.

DiMaggio, P. J., \& Powell, W. W. (1983). The Iron Cage Revisited: Institutional Isomorphism and Collective Rationality in Organizational Fields. American Sociological Review, 48(2), 147-160. https://doi.org/10.2307/2095101

Ebrahim, A. (2005). Accountability Myopia: Losing Sight of Organizational Learning. Nonprofit and Voluntary Sector Quarterly, 34(1), 56-87. https://doi.org/10.1177/0899764004269430

Edwards, M., \& Hulme, D. (1996). Too close for comfort? the impact of official aid on nongovernmental organizations. World Development, 24(6), 961-973. https://doi.org/10.1016/0305-750X(96)00019-8

Eikenberry, A. M., \& Kluver, J. D. (2004). The Marketization of the Nonprofit Sector: Civil Society at Risk? Public Administration Review, 64(2), 132-140. https://doi.org/10.1111/j.1540-6210.2004.00355.x

Elsevier. (2017). About Scopus. Retrieved May 24, 2017, from https://www.elsevier.com/solutions/scopus

Gazley, B., \& Guo, C. (2015). What do we know about nonprofit collaboration? A comprehensive systematic review of the literature. Proceedings of the Seventy-Fifth Annual Meeting of the Academy of Management.

Glaser, B. G., \& Strauss, A. L. (1967). The Discovery of Grounded Theory: Strategies for Qualitative Research. Aldine Publishing Company.

Guo, C., \& Acar, M. (2005). Understanding Collaboration Among Nonprofit Organizations: Combining Resource Dependency, Institutional, and Network Perspectives. Nonprofit and Voluntary Sector Quarterly, 34(3), 340-361. https://doi.org/10.1177/0899764005275411

Hall, P. D. (1999). The Work of Many Hands: A Response to Stanley N. Katz on the Origins of the "Serious Study" of Philanthropy. Nonprofit and Voluntary Sector Quarterly, 28(4), 522-534. https://doi.org/10.1177/0899764099284013

Hall, P. D. (2006). A Historical Overview of Philanthropy, Voluntary Associations, and Nonprofit Organizations in the United States, 1600-2000. In W. W. Powell \& R. Steinberg (Eds.), The nonprofit sector: A research handbook (pp. 32-65). Yale University Press.

Hanneman, R. A., \& Riddle, M. (2011). Concepts and Measures for Basic Network Analysis. In J. Scott \& P. Carrington, The SAGE Handbook of Social Network Analysis (pp. 340-369). 1 Oliver's Yard, 55 City Road, London EC1Y 1SP United Kingdom: SAGE Publications Ltd. Retrieved from http://srmo.sagepub.com/view/the-sage-handbook-ofsocial-network-analysis/n24.xml 
Hu, Q., Khosa, S., \& Kapucu, N. (2015). The Intellectual Structure of Empirical Network Research in Public Administration. Journal of Public Administration Research and Theory. https://doi.org/10.1093/jopart/muv032

Jackson, S. K., Guerrero, S., \& Appe, S. (2014). The State of Nonprofit and Philanthropic Studies Doctoral Education. Nonprofit and Voluntary Sector Quarterly, 43(5), 795-811. https://doi.org/10.1177/0899764014549056

Katz, S. N. (1999). Where Did the Serious Study of Philanthropy Come From, Anyway? Nonprofit and Voluntary Sector Quarterly, 28(1), 74-82. https://doi.org/10.1177/0899764099281006

Korff, V. P., Oberg, A., \& Powell, W. W. (2015). Interstitial organizations as conversational bridges. Bulletin of the American Society for Information Science and Technology, 41(2), 34-38. https://doi.org/10.1002/bult.2015.1720410210

Kuhn, T. S. (1970). The Structure of Scientific Revolutions (Second Edition, Enlarged). Chicago: University of Chicago Press.

Meyer, J. W., \& Rowan, B. (1977). Institutionalized Organizations: Formal Structure as Myth and Ceremony. American Journal of Sociology, 83(2), 340-363.

Mirabella, R. M. (2007). University-Based Educational Programs in Nonprofit Management and Philanthropic Studies: A 10-Year Review and Projections of Future Trends. Nonprofit and Voluntary Sector Quarterly, 36(4 suppl), 11S-27S. https://doi.org/10.1177/0899764007305051

Mirabella, R. M., \& Wish, N. B. (2001). University-Based Educational Programs in the Management of Nonprofit Organizations: An Updated Census of U.S. Programs. Public Performance \& Management Review, 25(1), 30-41. https://doi.org/10.2307/3381167

Morris, S. A., Yen, G., Wu, Z., \& Asnake, B. (2003). Time line visualization of research fronts. Journal of the American Society for Information Science and Technology, 54(5), 413422. https://doi.org/10.1002/asi.10227

Musick, M. A., \& Wilson, J. (2008). Volunteers: A Social Profile. Indiana University Press.

Musick, M. A., Wilson, J., \& Bynum, W. B. (2000). Race and Formal Volunteering: The Differential Effects of Class and Religion. Social Forces, 78(4), 1539-1570. https://doi.org/10.2307/3006184

Ni, C., Sugimoto, C. R., \& Robbin, A. (2017). Examining the Evolution of the Field of Public Administration through a Bibliometric Analysis of Public Administration Review. Public Administration Review. https://doi.org/10.1111/puar.12737

Noyons, E. (2001). Bibliometric mapping of science in a policy context. Scientometrics, 50(1), 83-98. https://doi.org/10.1023/A:1005694202977

Payton, R. L., \& Moody, M. P. (2008). Understanding Philanthropy: Its Meaning and Mission. Bloomington: Indiana University Press.

Peirson, E. (2016). Tethne (Version 0.8) [Python]. Arizona State University. Retrieved from http://diging.github.io/tethne/

Persson, O. (1994). The intellectual base and research fronts of JASIS 1986-1990. Journal of the American Society for Information Science, 45(1), 31-38. https://doi.org/10.1002/(SICI)1097-4571(199401)45:1<31::AID-ASI4>3.0.CO;2-G

Pfeffer, J., \& Salancik, G. R. (1978). The external control of organizations: a resource dependence perspective. Harper \& Row.

Pierre Bourdieu. (1986). The Forms of Capital. In J. G. Richardson (Ed.), Handbook of Theory and Research for the Sociology of Education (pp. 241-258). New York: Greenwood Press.

Price, D. J. de S. (1965). Networks of Scientific Papers. Science, 149(3683), 510-515. https://doi.org/10.1126/science.149.3683.510

Putnam, R. D. (1995). Bowling Alone: America's Declining Social Capital. Journal of Democracy, 6(1), 65-78. https://doi.org/10.1353/jod.1995.0002 
Putnam, R. D. (2000). Bowling Alone: The Collapse and Revival of American Community. Simon and Schuster.

Putnam, R. D., Leonardi, R., \& Nanetti, R. (1993). Making Democracy Work: Civic Traditions in Modern Italy. Princeton: Princeton University Press.

Salamon, L. M. (1987a). Of Market Failure, Voluntary Failure, and Third-Party Government: Toward a Theory of Government-Nonprofit Relations in the Modern Welfare State. Nonprofit and Voluntary Sector Quarterly, 16(1-2), 29-49. https://doi.org/10.1177/089976408701600104

Salamon, L. M. (1987b). Partners in Public Service: The Scope and Theory of GovernmentNonprofit Relations. In W. W. Powell (Ed.), The Nonprofit sector: a research handbook (pp. 99-117). New Haven: Yale University Press.

Salamon, L. M. (1995). Partners in Public Service: Government-Nonprofit Relations in the Modern Welfare State. Baltimore, Md: Johns Hopkins University Press.

Salamon, L. M. (2012). Government-nonprofit relations from an international perspective. In J. S. Ott \& L. A. Dicke (Eds.), The Nature of the Nonprofit Sector (2nd ed, pp. 367-384). Philadelphia, PA: Westview Press.

Salamon, L. M., \& Anheier, H. K. (1998). Social origins of civil society: Explaining the nonprofit sector cross-nationally. Voluntas: International Journal of Voluntary and Nonprofit Organizations, 9(3), 213-248.

Schuller, T., Baron, S., \& Field, J. (2000). Social Capital: A Review and Critique. In Social Capital: Critical Perspectives (First Edition, pp. 1-38). Oxford; New York: Oxford University Press.

Shier, M. L., \& Handy, F. (2014). Research Trends in Nonprofit Graduate Studies A Growing Interdisciplinary Field. Nonprofit and Voluntary Sector Quarterly, 43(5), 812-831. https://doi.org/10.1177/0899764014548279

Simon, K. W. (2013). Civil Society in China: The Legal Framework from Ancient Times to the "New Reform Era." Oxford University Press. Retrieved from http://www.oxfordscholarship.com/view/10.1093/acprof:oso/9780199765898.001.0001/a cprof-9780199765898

Small, H. (1973). Co-citation in the Scientific Literature: A New Measure of the Relationship Between Two Documents. Journal of the American Society for Information Science (Pre1986), 24(4). Retrieved from http://search.proquest.com/docview/216621298/abstract/9DE3379098C9422CPQ/1?acco untid=7398

Small, H. (1999). Visualizing science by citation mapping. Journal of the American Society for Information Science, 50(9), 799-813. https://doi.org/10.1002/(SICI)10974571(1999)50:9<799::AID-ASI9>3.0.CO;2-G

Smith, D. H. (2013). Growth of research associations and journals in the emerging discipline of altruistics. Nonprofit and Voluntary Sector Quarterly, 0899764013495979.

Wagner, A. (2012). “Third Sector” and/or "Civil Society”: A Critical Discourse About Scholarship Relating to Intermediate Organisations. Voluntary Sector Review, 3(3), 299328. https://doi.org/10.1332/204080512X658036

Weisbrod, B. A. (1975). Toward a Theory of the Voluntary Nonprofit Sector in a Three-Sector Economy. In E. S. Phelps (Ed.), Altruism, Morality, and Economic Theory (First Edition edition). New York: Russell Sage Foundation.

Weisbrod, B. A. (1977). The voluntary nonprofit sector: an economic analysis. Lexington Books. Wilson, J. (2000). Volunteering. Annual Review of Sociology, 26(1), 215-240. https://doi.org/10.1146/annurev.soc.26.1.215

Wilson, J., \& Musick, M. (1997). Who Cares? Toward an Integrated Theory of Volunteer Work. American Sociological Review, 62(5), 694-713. 
Wilson, J., \& Musick, M. (1999). The Effects of Volunteering on the Volunteer. Law and Contemporary Problems, 62(4), 141-168. https://doi.org/10.2307/1192270

Wolfgang, B. (2004). Social Capital. In Burlingame, Dwight F. (Ed.), Encyclopedia of Philanthropy in the US. San Francisco: ABC-CLIO Publishing. 